\title{
26. MAJOR ELEMENT CHEMISTRY AND MICROPROBE STUDIES OF BASALTS FROM DEEP SEA DRILLING PROJECT LEG 51, SITE 417
}

\author{
Tadahide Ui, Department of Earth Sciences, Faculty of Science, Kobe University, Kobe 657, Japan \\ Hiroshi Haramura, Geological Institute, Faculty of Science, University of Tokyo, Tokyo 113, Japan \\ and \\ Hideo Nagai, ${ }^{1}$ Department of Earth Sciences, Faculty of Science, Kanazawa University, Kanazawa 920, Japan
}

\begin{abstract}
Basalts recovered from Hole 417A, Leg 51, show a high degree of leaching of $\mathrm{Mg}, \mathrm{Ca}$, and $\mathrm{Na}$, addition of $\mathrm{K}$, hydration, and oxidation as a result of ocean-floor weathering. Basalts from Hole 417D are relatively fresh having slightly higher $\mathrm{FeO}^{* 2} / \mathrm{MgO}$ ratios ( 1.3 to 1.7$)$, higher $\mathrm{CaO}$ content, and lower $\mathrm{SiO}_{2}, \mathrm{Na}_{2} \mathrm{O}$, and $\mathrm{K}_{2} \mathrm{O}$ contents compared with abyssal basalts from the $25-37^{\circ} \mathrm{N}$ portion of the present Mid-Atlantic Ridge. Compositional gaps are found at 365 meters, 397 meters, and 491 meters sub-bottom in Hole 417D. A pillow basalt unit between 365 meters and 397 meters sub-bottom shows a progressive increase in size and content of plagioclase with depth and a progressive change in bulk $\mathrm{Al}_{2} \mathrm{O}_{3}, \mathrm{MgO}$, and $\mathrm{FeO}^{*}$ contents. These findings suggest gravitational fractionation in the magma reservoir. Aphyric zones with different composition, phase chemistry, and texture occur in the middle part of a pillowed lava, at a depth of $\mathbf{4 3 5}$ meters to 491 meters. Dike intrusion and auto-intrusion are possible models for this aphyric part.
\end{abstract}

\section{INTRODUCTION}

On IPOD-DSDP Leg 51, we drilled at the western part of the Atlantic Ocean $\left(25^{\circ} \mathrm{N}, 68^{\circ} \mathrm{W}\right)$ between November 1976 and January 1977 (Figure 1). One of the main purposes of this leg and Legs 52 and 53 was to make the first deep drilling into Layer 2 in Cretaceous crust (Bryan et al., 1977; Donnelly et al., 1977; Flower et al., 1977). From Hole 417A, we recovered 206 meters of pillow basalts, pillow breccia, and massive units below 211 meters of sediments. In Hole 417D, 189 meters of pillow lava and massive basalt below 343 meters of sediment were drilled, and drilling was continued on Leg 52 to a depth of 708 meters. In this paper, we present the results of major-oxide analyses of rocks and minerals, as well as some preliminary discussions. Samples for this study were collected by one of the authors (T.U.) on Leg 51. Ten additional samples from the lower levels of Hole 417D were collected during Leg 52. ${ }^{3}$ Positions of all the samples are shown in Figure 2.

\footnotetext{
'Present address: Ricoh Kyoiku Kiki Co., Ltd., Jinnan, Shibuya, Tokyo 150, Japan.

${ }^{2} \mathrm{FeO}^{*}=$ total $\mathrm{Fe}$ content.

${ }^{3}$ Wet-chemical analyses for bulk rock samples were carried out by H. Haramura at the University of Tokyo. Major-oxide analyses of chilled glassy rims and primary minerals were carried out by T.U. and H.N., using a Hitachi XMA-5 electron microprobe analyzer at Kanazawa University. Reduction of microanalyzer data was conducted at the Computation Center, Kobe University. Petrographical studies were done at the Department of Earth Sciences, Kobe University.
}

\section{CHEMISTRY}

Major-element wet-chemical analyses were carried out for nine rock samples from Hole 417A (including interlaboratory standard, Sample 44-3, 58-68 cm) and for 17 samples from Hole 417D. Results are listed in Table 1, together with those of interlaboratory standard sample WHOI No. AII92-29-1.

\section{Hole 417A}

The samples from Hole 417A (Figure 3) show an increasing degree of leaching of $\mathrm{Mg}, \mathrm{Ca}$, and $\mathrm{Na}$, addition of $\mathrm{K}$, hydration, and oxidation towards the surface of Layer 2. $\mathrm{K}_{2} \mathrm{O}$ shows the most drastic change. Deeper level samples of Hole $417 \mathrm{~A}$ basalt show a $\mathrm{K}_{2} \mathrm{O}$ content of 0.07 per cent to 0.08 per cent, which is similar to that of relatively fresh samples from Hole 417D. By comparison, the specimen collected from 219 meters sub-bottom near the sediment/ basement contact (Sample 417A-24-1, 111-116 cm) contains 6.7 per cent $\mathrm{K}_{2} \mathrm{O}$. The $\mathrm{K}_{2} \mathrm{O}$ content increases rapidly uphole at depths shallower than 260 meters sub-bottom, while $\mathrm{H}_{2} \mathrm{O}^{+}$increases uphole between 0.8 per cent and 1.4 per cent to 5.8 per cent, $\mathrm{H}_{2} \mathrm{O}$ - between 0.6 per cent and 0.7 per cent to 4.7 per cent, and $\mathrm{Fe}_{2} \mathrm{O}_{3}$ between 3.5 per cent and 4.0 per cent to 7.5 per cent. Oxidation increases upward steadily through the entire section. On the other hand, $\mathrm{FeO}$ decreases uphole between 6.1 per cent and 6.3 per cent to 0.5 per cent, while $\mathrm{MgO}$ decreases between 6.9 per cent and 7.0 per cent to 2.6 per cent, $\mathrm{CaO}$ between 12 per cent and 13 per cent to 3.0 per cent, and $\mathrm{Na}_{2} \mathrm{O}$ from 2.2 per cent to 1.4 per cent. The depletion of $\mathrm{Mg}, \mathrm{Ca}$, and $\mathrm{Na}$ is thus increasingly 


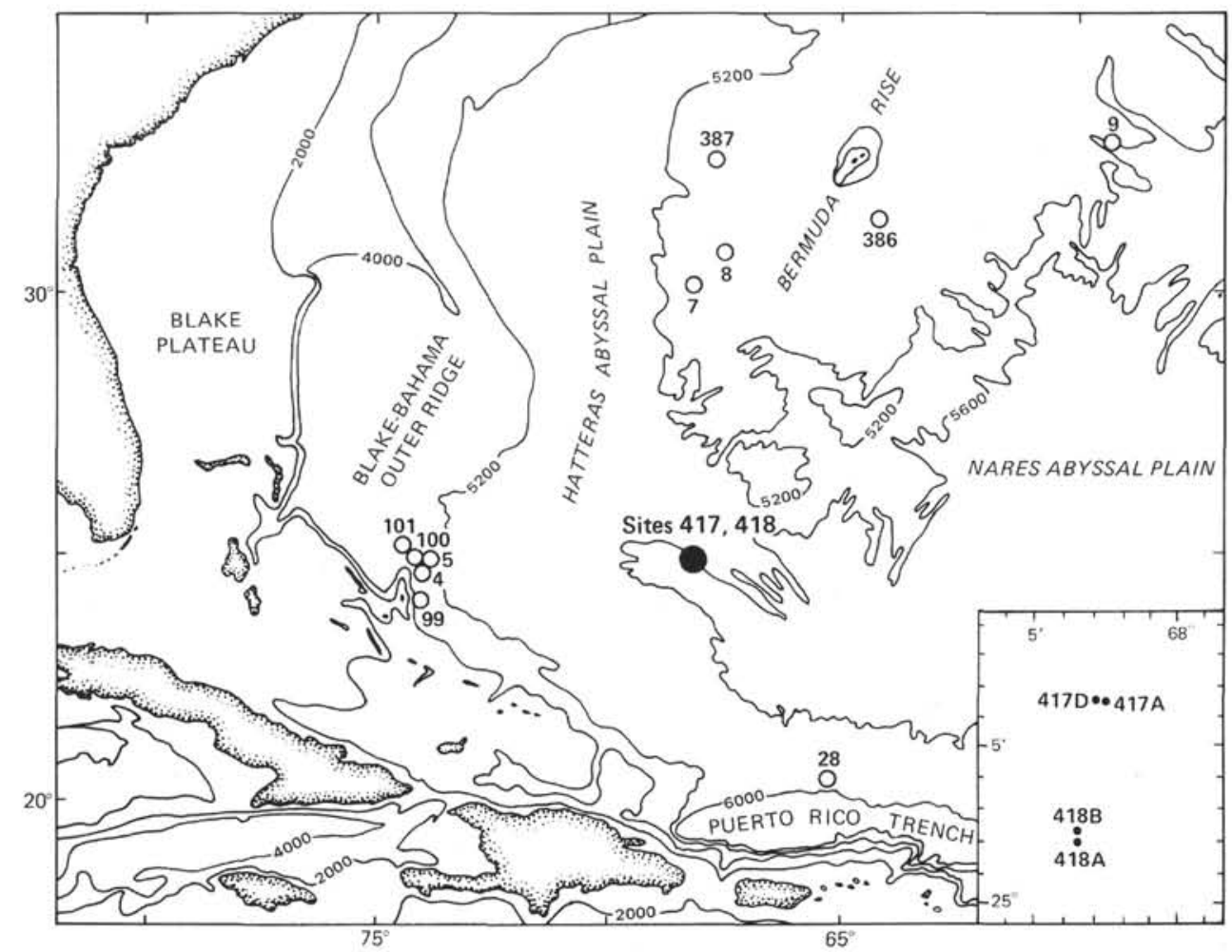

Figure 1. Site locations, Legs 51 through 53.

pronounced above 260 meters. An abrupt decrease in $\mathrm{FeO}^{*}$ content for the shallowest sample suggests the possibility of Fe leaching. The amount of $\mathrm{SiO}_{2}, \mathrm{TiO}_{2}$, and $\mathrm{Al}_{2} \mathrm{O}_{3}$ is variable throughout the interval analyzed. Although we cannot distinguish compositional zoning, these results are consistent with shipboard XRF analyses, and with sea-floor weathering (Hart, 1970; Shido et al., 1974; Donnelly et al., 1977).

\section{Hole 417D}

The following chemical patterns are evident from the analytical data for Hole 417D (Figure 4).

1) A slight and gradual compositional change is seen through the interval between 365 meters and 397 meters sub-bottom. $\mathrm{SiO}_{2}$ and $\mathrm{Al}_{2} \mathrm{O}_{3}$ increase 2.6 wt. $\%$ and 1.4 wt. \%, respectively, with depth, while $\mathrm{FeO}^{*}, \mathrm{MgO}$, and $\mathrm{CaO}$ decrease 1.5 per cent, 1.3 per cent, and 1.2 per cent, respectively, with depth.

2) Sample 417D-41-7, 80-86 cm from 484 meters subbottom (Analysis 22, Table 1) has lower than average $\mathrm{TiO}_{2}$, $\mathrm{Fe}_{2} \mathrm{O}_{3}$, and $\mathrm{Na}_{2} \mathrm{O}$ contents and higher $\mathrm{FeO}^{*}$ and $\mathrm{MgO}$ contents. From modal analysis, the total volume percentage of phenocrysts is extremely high, approximately $31 \mathrm{vol}$. \%. In this sample, many of the olivine and most of the clinopyroxene phenocrysts remain as fresh primary phases. The composition of this sample may thus be explained by the presence of fresh phenocrysts.

3) $417 \mathrm{D}-38-6,52-57 \mathrm{~cm}$ and 417D-39-3, 88-95 $\mathrm{cm}$ from 464 meters and 468 meters sub-bottom, respectively (Analyses 20 and 21, Table 1) show higher than normal concentrations of $\mathrm{TiO}_{2}, \mathrm{FeO}^{*}$, and $\mathrm{Na}_{2} \mathrm{O}$ (by approximately $0.2 \%$ to $0.3 \%$ for all three oxides) and a slight depletion of $\mathrm{CaO}$ and $\mathrm{Al}_{2} \mathrm{O}_{3}$ (by $1.0 \%$ and $1.2 \%$, respectively). The cause of this compositional variation will be discussed in a later section.

4) A fractured zone, possibly a fault, was described at 491 meters sub-bottom (Donnelly et al., 1977). Below that level, the basalts become less porphyritic. Compositional discontinuities around this level are clear; i.e., a 1.0 per cent decrease in $\mathrm{Al}_{2} \mathrm{O}_{3}$, a 0.5 per cent decrease in $\mathrm{CaO}$, a 0.7 per cent increase in $\mathrm{MgO}$, and a 0.3 per cent increase in $\mathrm{FeO}^{*}$ below the boundary. These changes of chemistry are qualitatively consistent with a decrease in modal plagioclase. No compositional variations attributable to weathering are detected for the samples from Hole 417D. Surface weathering was described at the top of the basement section (Donnelly et al., 1977), but samples from this level are not included in our study.

Fresh glassy rims were frequently found in the recovered core from Hole 417D. Usually such rims are partially devitrified to a dark brownish material, especially along cracks and grain boundaries. Most of the cracks are filled with secondary minerals. The degree of devitrification increases toward the inner microcrystalline zone in each specimen. Patches of glass wide enough for microprobe analyses were available in 20 of the 27 chilled rim samples collected. Unfortunately, no fresh glass sample was available from Hole 417A.

Table 2 presents the glass analysis results. Duplicate or triplicate analyses were made for some samples. Interlaboratory standard WHOI No. AII 92-11-5 was also analyzed under identical conditions and the results are listed in Table 2. Our standard glass data are 0.6 per cent and 0.13 per cent higher in $\mathrm{CaO}$ and $\mathrm{Na}_{2} \mathrm{O}$, respectively, than those obtained at the Smithsonian Institution (Jarosewich, personal communication). Agreement for the other major 

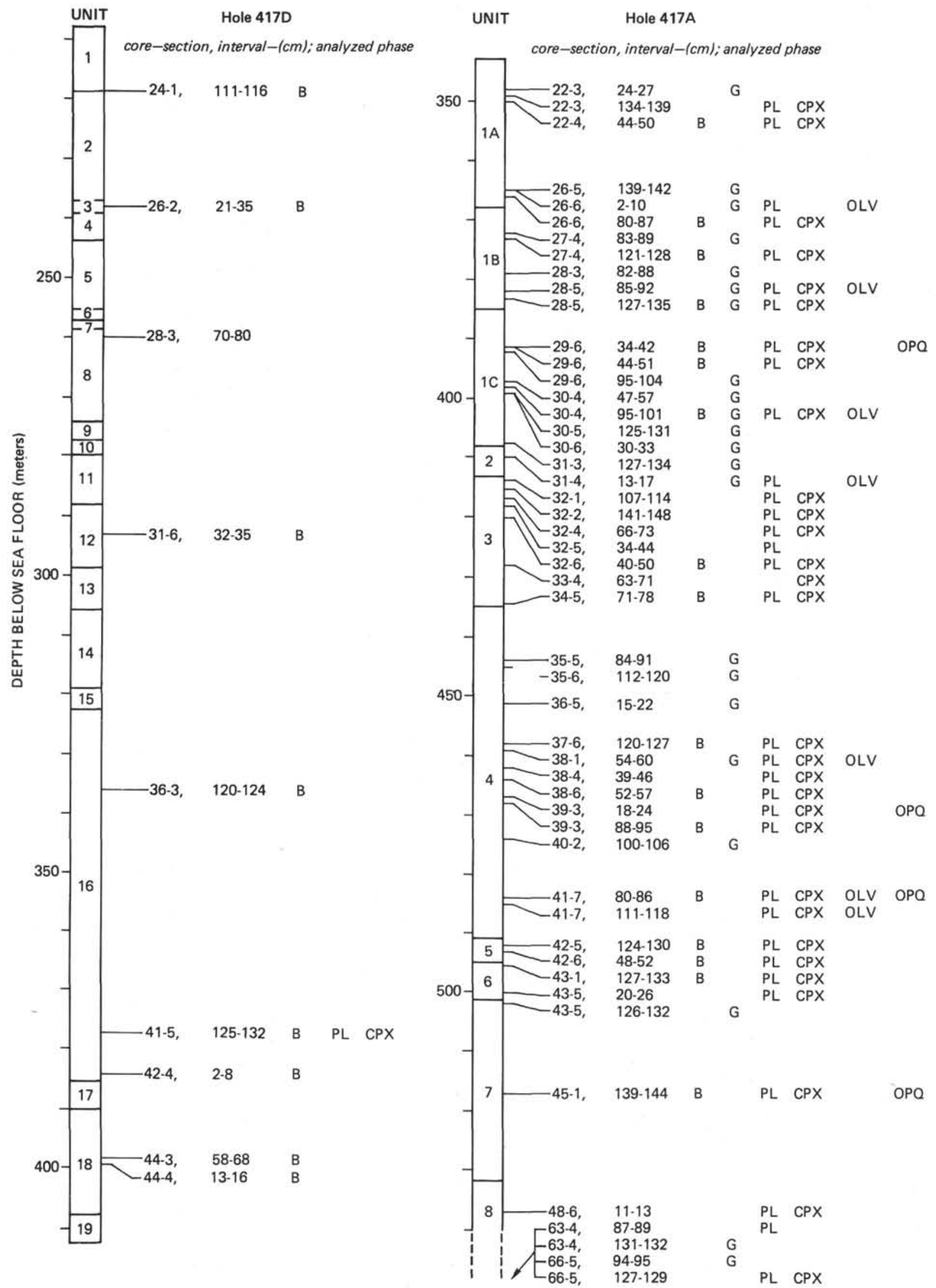

Figure 2. Lithologic units in Holes $417 A$ and $417 D$, showing location of samples analyzed in this study. Abbreviations are as follows: $B=$ bulk; $G=$ glass; $P L=$ plagioclase $; C P X=$ clinopyroxene; $O L V=$ olivine; and $O P Q=$ opaque minerals. 


\begin{tabular}{|c|c|c|c|c|c|c|c|c|c|c|c|c|c|c|c|c|c|c|c|c|c|c|c|c|c|c|c|}
\hline & 1 & 2 & 3 & 4 & 5 & 6 & 7 & 8 & 9 & 10 & 11 & 12 & 13 & 14 & 15 & 16 & 17 & 18 & 19 & 20 & 21 & 22 & 23 & 24 & 25 & 26 & 27 \\
\hline $\mathrm{SiO}_{2}$ & 48.14 & 45.89 & 45.47 & 44.76 & 46.18 & 48.06 & 45.79 & 48.59 & 48.66 & 46.83 & 47.53 & 46.31 & 47.21 & 47.94 & 47.56 & 48.96 & 47.99 & 46.64 & 46.97 & 46.71 & 48.42 & 47.42 & 47.12 & 46.49 & 47.31 & 46.69 & 48.79 \\
\hline $\mathrm{TiO}_{2}^{2}$ & 1.47 & 2.13 & 1.43 & 1.28 & 1.37 & 1.35 & 1.47 & 1.52 & 1.39 & 1.38 & 1.29 & 1.43 & 1.43 & 1.37 & 1.41 & 1.34 & 1.46 & 1.49 & 1.43 & 1.79 & 1.69 & 1.08 & 1.56 & 1.57 & 1.60 & 1.68 & 1.81 \\
\hline $\mathrm{Al}_{2} \mathrm{O}_{3}$ & 17.67 & 16.18 & 17.07 & 16.79 & 17.23 & 16.47 & 16.41 & 16.32 & 15.85 & 16.64 & 17.04 & 16.58 & 17.35 & 17.56 & 17.92 & 16.58 & 15.87 & 16.97 & 16.27 & 15.08 & 15.14 & 15.93 & 15.32 & 14.81 & 15.57 & 16.09 & 16.15 \\
\hline $\mathrm{Fe}_{2} \mathrm{O}_{3}$ & 7.48 & 7.53 & 6.64 & 7.06 & 4.73 & 4.54 & 5.42 & 4.07 & 3.54 & 4.25 & 3.85 & 4.57 & 4.18 & 3.72 & 4.32 & 2.15 & 3.82 & 4.36 & 3.76 & 4.14 & 4.12 & 2.36 & 3.87 & 4.44 & 5.31 & 4.93 & 2.13 \\
\hline $\mathrm{FeO}$ & 0.49 & 3.41 & 3.37 & 3.83 & 3.64 & 5.71 & 3.99 & 6.13 & 6.32 & 5.17 & 5.94 & 5.10 & 4.88 & 5.07 & 4.07 & 7.70 & 5.91 & 4.69 & 6.02 & 5.95 & 6.02 & 6.90 & 6.25 & 5.41 & 4.95 & 4.88 & 7.82 \\
\hline $\mathrm{MnO}$ & 0.13 & 0.18 & 0.16 & 0.15 & 0.15 & 0.16 & 0.15 & 0.17 & 0.16 & 0.18 & 0.16 & 0.16 & 0.17 & 0.15 & 0.12 & 0.15 & 0.15 & 0.17 & 0.20 & 0.23 & 0.20 & 0.19 & 0.17 & 0.17 & 0.14 & 0.17 & 0.17 \\
\hline $\mathrm{MgO}$ & 2.61 & 6.42 & 6.37 & 5.64 & 4.99 & 6.16 & 4.81 & 7.06 & 6.90 & 6.89 & 6.89 & 6.31 & 5.44 & 6.13 & 5.55 & 5.69 & 6.41 & 6.41 & 6.65 & 7.23 & 6.61 & 9.56 & 7.37 & 7.20 & 6.40 & 7.10 & 7.61 \\
\hline $\mathrm{CaO}$ & 3.00 & 9.46 & 11.32 & 11.54 & 13.19 & 12.93 & 13.76 & 12.28 & 12.65 & 12.52 & 12.59 & 12.73 & 12.64 & 12.48 & 11.71 & 11.51 & 12.73 & 11.85 & 12.94 & 11.89 & 12.04 & 12.20 & 12.45 & 12.56 & 10.94 & 10.72 & 11.19 \\
\hline $\mathrm{Na}_{2} \mathrm{O}$ & 1.43 & 2,01 & 2.17 & 2.06 & 2.31 & 2.13 & 2.13 & 2.21 & 2.21 & 2.36 & 2.31 & 2.25 & 2.38 & 2.23 & 2.34 & 2.14 & 2.26 & 2.43 & 2.19 & 2.42 & 2.52 & 1.79 & 2.25 & 2.23 & 2.56 & 2.51 & 2.83 \\
\hline $\mathrm{K}_{2} \mathrm{O}$ & 6.72 & 1.84 & 0.73 & 0.90 & 0.88 & 0.07 & 0.59 & 0.08 & 0.08 & 0.08 & 0.09 & 0.12 & 0.05 & 0.04 & 0.07 & 0.26 & 0.09 & 0.06 & 0.05 & 0.07 & 0.10 & 0.06 & 0.04 & 0.08 & 0.53 & 0.10 & 0.17 \\
\hline $\mathrm{H}_{2} \mathrm{O}^{+}$ & 5.79 & 3.37 & 3.35 & 3.86 & 3.69 & 1.66 & 3.62 & 0.80 & 1.41 & 1.92 & 1.46 & 2.27 & 1.93 & 1.52 & 2.14 & 1.85 & 2.04 & 2.03 & 1.89 & 2.21 & 1.77 & 1.84 & 1.55 & 2.72 & 2.06 & 1.93 & 0.78 \\
\hline $\mathrm{H}_{2}^{2} \mathrm{O}^{-}$ & 4.71 & 1.68 & 2.09 & 1.87 & 1.45 & 0.72 & 1.82 & 0.62 & 0.72 & 1.67 & 1.12 & 1.70 & 2.16 & 1.40 & 2.39 & 1.20 & 0.95 & 2.42 & 1.22 & 1.99 & 1.09 & 0.70 & 1.80 & 2.07 & 2.29 & 2.82 & 0.34 \\
\hline $\mathrm{P}_{2}^{2} \mathrm{O}_{5}$ & 0.20 & 0.21 & 0.22 & 0.19 & 0.28 & 0.18 & 0.28 & 0.14 & 0.28 & 0.20 & 0.11 & 0.14 & 0.11 & 0.14 & 0.14 & 0.14 & 0.13 & 0.13 & 0.13 & 0.16 & 0.16 & 0.10 & 0.15 & 0.14 & 0.16 & 0.04 & 0.26 \\
\hline Total & 99.84 & 100.31 & 100.39 & 99.93 & 100.09 & 100.14 & 100.24 & 99.99 & 100.17 & 100.09 & 100.38 & 99.67 & 99.93 & 99.75 & 99.74 & 99.67 & 99.81 & 99.65 & 99.72 & 99.87 & 99.88 & 100.13 & 99.90 & 99.89 & 99.82 & 99.66 & 100.05 \\
\hline Q & 0.21 & 0.0 & 0.0 & 0.0 & 0.8 & 0.0 & 0.0 & 0.0 & 0.8 & 0. & 0. & 0. & 0.8 & 0.0 & 0.12 & 1.40 & 0.0 & & 0.0 & 0.0 & 0.0 & 0.0 & 0.0 & 0.0 & 0.0 & 0.0 & 0.0 \\
\hline Or & 39.7 & 10.9 & 4.31 & 5.32 & 5.20 & 0.41 & 3.49 & 0.47 & 0.47 & 0.47 & 0.53 & 0.71 & 0.30 & 0.24 & 0.41 & 1.54 & 0.53 & 0.36 & 0.30 & 0.41 & 0.59 & 0.36 & 0.24 & 0.47 & 3.13 & 0.59 & 1.01 \\
\hline $\mathrm{Ab}$ & 12.1 & 17.0 & 18.4 & 17.4 & 17.4 & 18.0 & 17.5 & 18.7 & 18.7 & 20.0 & 19.5 & 19.0 & 21.1 & 18.9 & 19.8 & 18.1 & 19.1 & 20.6 & 18.5 & 20.5 & 21.3 & 15.1 & 19.0 & 18.9 & 21.7 & 21.2 & 23.9 \\
\hline An & 13.6 & 29.7 & 34.7 & 33.9 & 34.0 & 35.2 & 33.5 & 34.4 & 33.1 & 34.6 & 35.9 & 34.8 & 36.5 & 37.8 & 38.2 & 34.9 & 32.9 & 35.2 & 34.4 & 30.1 & 29.7 & 35.3 & 31.6 & 30.2 & 29.4 & 32.3 & 30.9 \\
\hline c & 3.07 & 0.0 & 0.0 & 0.0 & 0.0 & 0.0 & 0.0 & 0.0 & 0.0 & 0.0 & 0.0 & 0.0 & 0.0 & 0.0 & 0.0 & 0.0 & 0.0 & 0.0 & 0.0 & 0.0 & 0.0 & 0.0 & 0.0 & 0.0 & 0.0 & 0 & 0.0 \\
\hline Di & 0.0 & 13.0 & 16.5 & 18.3 & 24.3 & 22.9 & 27.2 & 21.0 & 22.8 & 21.5 & 21.2 & 22.5 & 21.0 & 19.0 & 15.6 & 17.6 & 24.1 & 18.6 & 23.7 & 22.8 & 23.8 & 20.0 & 23.9 & 25.5 & 19.5 & 16.8 & 18.7 \\
\hline Hy & 15.6 & 5.65 & 3.67 & 0.47 & 0.0 & 13.4 & 0.0 & 15.0 & 15.3 & 5.47 & 6.76 & 4.99 & 9.35 & 14.4 & 16.5 & 18.6 & 11.8 & 8.73 & 7.30 & 7.77 & 12.4 & 13.0 & 8.68 & 6.95 & 8.55 & 11.2 & 8.82 \\
\hline OI & 0.0 & 12.2 & 12.2 & 13.7 & 7.92 & 2.92 & 7.49 & 3.92 & 2.55 & 9.7 & 9.39 & 8.76 & 3.90 & 2.00 & 0.0 & 0.0 & 3.52 & 6.89 & 7.54 & 8.51 & 3.76 & 9.99 & 7.97 & 7.95 & 7.75 & 7.54 & 9.85 \\
\hline Mt & 1.16 & 1.64 & 1.51 & 1.64 & 1.27 & 1.58 & 1.43 & 1.58 & 1.53 & 1.45 & 1.52 & 1.49 & 1.39 & 1.36 & 1.28 & 1.55 & 1.51 & 1.39 & 1.52 & 1.56 & 1.57 & 1.46 & 1.57 & 1.52 & 1.57 & 1.50 & 1.57 \\
\hline II & 2.79 & 4.05 & 2.72 & 2.43 & 2.60 & 2.56 & 2.79 & 2.89 & 2.64 & 2.6 & 2.4 & 2.72 & 2.72 & 2.60 & 2.68 & 2.5 & 2.77 & 2.83 & 2.72 & 3.40 & 3.21 & 2.05 & 2.96 & 2.98 & 3.04 & 3.19 & 3.44 \\
\hline Ap & 0.46 & 0.49 & 0.51 & 0.44 & 0.65 & 0.42 & 0.65 & 0.32 & 0.65 & 0.46 & 0.26 & 0.32 & 0.26 & 0.32 & 0.32 & 0.32 & 0.30 & 0.30 & 0.30 & 0.37 & 0.37 & 0.23 & 0.35 & 0.32 & 0.37 & 0.09 & 0.60 \\
\hline $\mathrm{Ne}$ & 0.0 & 0.0 & 0.0 & 0.0 & 1.16 & 0.0 & 0.28 & 0.0 & 0.0 & 0.0 & 0.0 & 0.0 & 0.0 & 0.0 & 0.0 & 0.0 & 0.0 & 0.0 & 0.0 & 0.0 & 0.0 & 0.0 & 0.0 & 0.0 & 0.0 & 0.0 & 0.0 \\
\hline
\end{tabular}

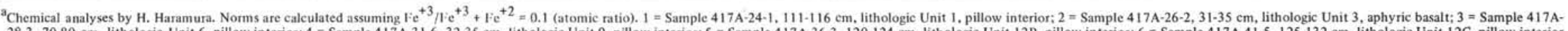
$28-3.70-80 \mathrm{~cm}$, lithologic Unit 6, pillow interior: $4=$ Sample $417 \mathrm{~A}-31-6,32-35 \mathrm{~cm}$, lithologic Unit 9, pillow interior; $5=$ Sample $417 \mathrm{~A}-36-3,120-124 \mathrm{~cm}$, lithologic Unit $12 \mathrm{~B}$, pillow interior; $6=$ Sample $417 \mathrm{~A}-41-5,125-132 \mathrm{~cm}$, lithologic Unit $12 \mathrm{C}$, pillow interior
$7=$ Sample $417 \mathrm{~A}-42-4,2-8 \mathrm{~cm}$, lithologic Unit $12 \mathrm{C}$, pillow interior; $8=$ Sample $417 \mathrm{~A}-44-3,58-68 \mathrm{~cm}$, lithologic Unit $15 \mathrm{~B}$, massive basalt (intertaboratory standard):9=Sample $417 \mathrm{~A}-44-4,13-16 \mathrm{~cm}$, lithologic Unit $15 \mathrm{~B}$, massive basalt; $10=$ Sample $417 \mathrm{D}-$ $22-4,44-50 \mathrm{~cm}$, lithologic Unit $1 \mathrm{~A}$, pillow interior; $11=$ Sample $417 \mathrm{D}-26-6,80-87 \mathrm{~cm}$, lithologic Unit $1 \mathrm{~A}$, pillow interior: $12=$ Sample $417 \mathrm{D}-27-4,121-128 \mathrm{~cm}$, lithologic Unit $1 \mathrm{~B}$, pillow interior, $13=S$ ample $417 \mathrm{D}-28-5,127-135 \mathrm{~cm}$, lithologic Unit $1 \mathrm{~B}$, pillow interior: $14=$ Sample $417 \mathrm{D}-29-6,34-42 \mathrm{~cm}$, lithologic Unit $1 \mathrm{C}$, pillow interior; rich in mafic phenoctysts: $15=$ Sample $417 \mathrm{D}, 29-6,44-51 \mathrm{~cm}$, lithologic Unit $1 \mathrm{C}$, pillow interior; rich in plagioclase phenocrysts; $16=$ Sample $417 \mathrm{D}-30-4,95-101 \mathrm{~cm}$, lithologic Unit $1 \mathrm{C}$,
chilled pillow rim; $17=$ Sample $417 \mathrm{D}-32-6,40-50 \mathrm{~cm}$, lithologic Unit 3 , massive basalt: $18=$ Sample $417 \mathrm{D}-34-5,71-78 \mathrm{~cm}$, lithologic Unit 3 , massive basalt, $30 \mathrm{~cm}$ from chilled rim: $19=$ Sample $417 \mathrm{D}-37-6,120-127 \mathrm{~cm}$, lithologic Unit 4 , pillow interior; $20=$ Sample 417D-38-6, $52-57 \mathrm{~cm}$, lithologic Unit 4, aphyric pillow basalt: $21=$ Sample $417 \mathrm{D}-39-3,88-95 \mathrm{~cm}$, lithologic Unit 4 , aphyric pillow basalt; $22=$ Sample $417 \mathrm{D}-41-7,80-86 \mathrm{~cm}$, lithologic Unit 4 , chilled pillow rim: $23=$ Sample $417 \mathrm{D}-42-5,124-130 \mathrm{~cm}$, lithologic Unit 5 , pillow interior; $24=$ Sample $417 \mathrm{D}-42-6,48-52 \mathrm{~cm}$, lithologic Unit 5 , pillow interior: $25=$ Sample $417 \mathrm{D}-43 \cdot 1,127 \cdot 133 \mathrm{~cm}$, lithologic Unit 6 , massive basalt chilled margin; $26=$ Sample $417 \mathrm{D}-45-1,139-144 \mathrm{~cm}$, lithologic Unit 7 , pillow interior,
$27=$ WHOI No. All $92-29-1$, Dredge sample from $23^{\circ} 02.64^{\prime} \mathrm{N}, 45^{\circ} 01.05^{\prime} \mathrm{W}$ (interlaboratory standard). 


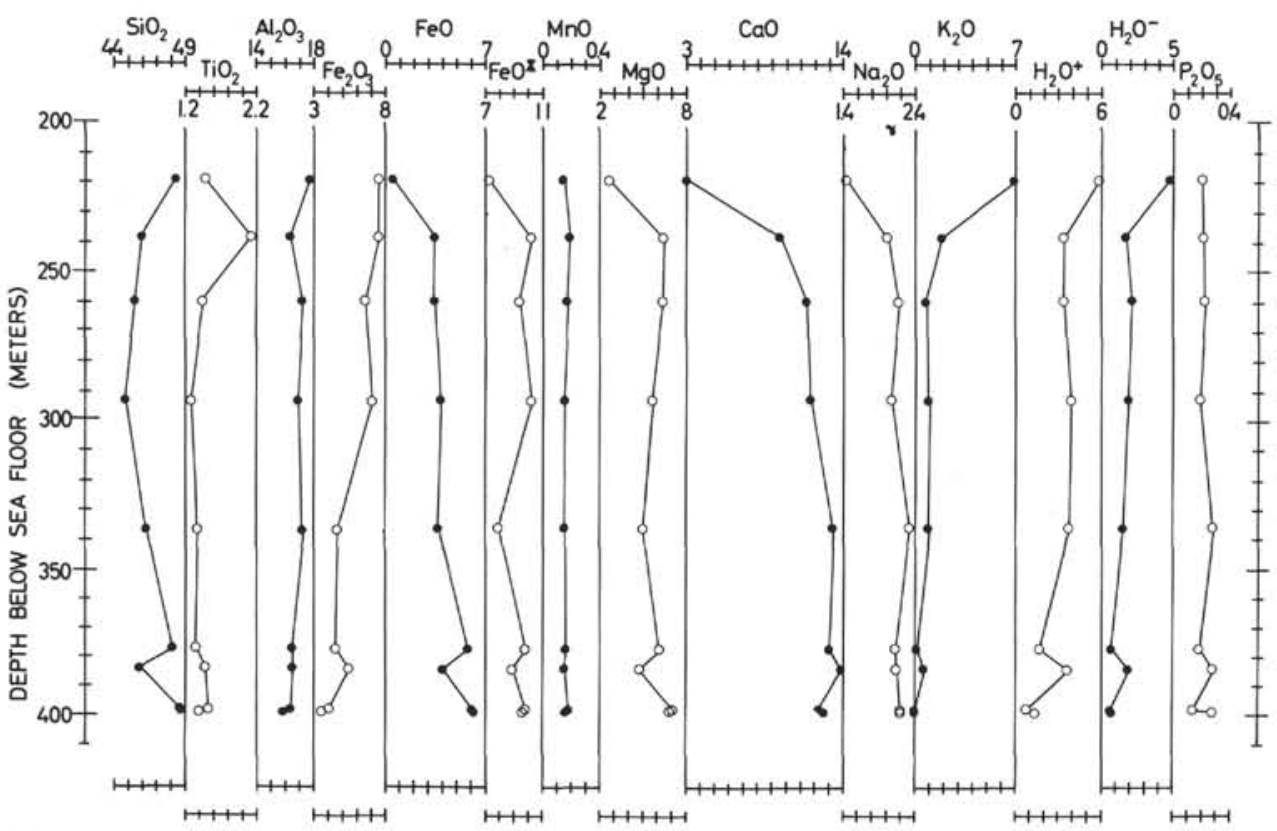

Figure 3. Oxide compositions in wt. \% versus depth for basalts from Hole $417 \mathrm{~A}$.

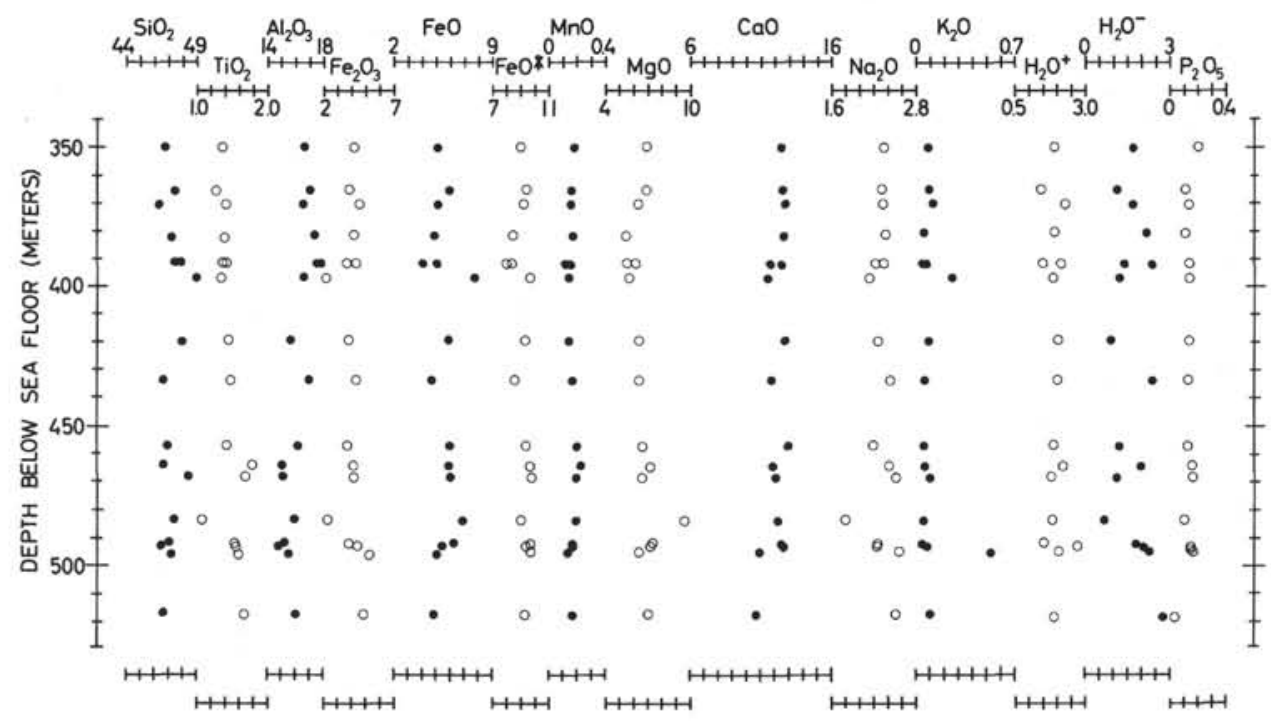

Figure 4. Oxide compositions in wt. \% versus depth for basalts from Hole 417D.

oxides is better. The deviation of the analytical results was checked by four duplicate or triplicate analyses. The standard deviation of the result for $\mathrm{Na}_{2} \mathrm{O}$ is 0.13 per cent, that for $\mathrm{FeO}^{*}$ is 0.2 per cent, and for $\mathrm{MgO}$ is 0.11 per cent.

The following inferences may be drawn from the glass analyses shown in Table 2: (1) Among all the samples analyzed, two from Leg 52 show distinctively higher $\mathrm{MgO}$ content (Figure 5). (2) Specimens from 365 to 397 meters sub-bottom (Samples 417D-26-6, 2-10 cm through 417D-30-4, 47-57 cm) show a slight increase in $\mathrm{MgO}$ toward the sediment/basalt contact. (3) The glass compositions for samples from 435 to 491 meters sub-bottom (Samples 417D-35-5, 84-91 cm through 417D-40-2, 100$106 \mathrm{~cm}$ ) are similar to those immediately above and below, but are 0.6 per cent higher in $\mathrm{FeO}^{*}$ compared with those from the 365 to 397 meter interval, while the $\mathrm{MgO}$ content is 0.3 per cent lower. (4) Two samples from 343 to 365 meters sub-bottom are 0.3 per cent higher in $\mathrm{FeO}^{*}$ than those from 365 to 397 meters sub-bottom.

According to these results, we have determined the chemical unit boundaries to be at 365,397 , and 491 meters subbottom for Hole 417D (Figure 6). It is not certain if there is a compositional gap at the boundaries between massive units and pillow lavas $(413 \mathrm{~m}, 435 \mathrm{~m}, 495 \mathrm{~m}$, and $501 \mathrm{me}-$ ters sub-bottom). No chemical breaks are found for the lithologic boundaries at 385 and 408 meters which were determined during the shipboard study. The rationale for distinguishing these two lithologic boundaries was the existence of interpillow breccias. Instead of this, interpillow carbonates are commonly found at and around the chemically distinct boundaries at 365 and 397 meters. In summary, we propose the revision of the unit boundaries shown in the right-hand column of Figure 6, and from this point our discussions are based on these proposed unit boundaries. 
TABLE 2

EPMA Analyses of Hole 417D Glasses

\begin{tabular}{|c|c|c|c|c|c|c|c|c|c|c|c|c|c|c|c|}
\hline Unit & 1 & & $1 \mathrm{~A}$ & $1 \mathrm{~A}$ & $1 \mathrm{~B}$ & $1 \mathrm{~B}$ & $1 \mathrm{~B}$ & $1 \mathrm{~B}$ & $1 \mathrm{C}$ & $1 \mathrm{C}$ & $1 \mathrm{C}$ & \multicolumn{2}{|c|}{$1 \mathrm{C}$} & IC & $1 \mathrm{C}$ \\
\hline $\begin{array}{c}\text { Sample } \\
\text { (Interval in } \mathrm{cm} \text { ) } \\
\end{array}$ & \multicolumn{2}{|c|}{$22-3,24-27$} & $26-5,139-142$ & $26-6,2-10$ & $27-4,83-89$ & $28-3,82-88$ & $28-5,85-92$ & $28-5,127-135$ & $29-6,95-104$ & $30-4,47-57$ & $30-4,95-101$ & $30-5,1$ & $25-131$ & $30-6,30-33$ & $31-3,127-134$ \\
\hline $\mathrm{SiO}_{2}$ & 50.2 & 50.1 & 49.6 & 49.8 & 50.1 & 49.9 & 49.9 & 50.0 & 49.9 & 49.9 & 49.8 & 49.9 & 49.6 & 50.0 & 50.0 \\
\hline $\mathrm{TiO}_{2}^{2}$ & 1.57 & 1.58 & 1.58 & 1.55 & 1.54 & 1.48 & 1.47 & 1.48 & 1.48 & 1.49 & 1.53 & 1.55 & 1.49 & 1.61 & 1.54 \\
\hline $\mathrm{Al}_{2} \mathrm{O}_{3}$ & 14.3 & 14.4 & 14.3 & 14.9 & 14.4 & 14.6 & 14.6 & 14.4 & 14.4 & 14.3 & 14.6 & 14.4 & 14.4 & 14.5 & 14.4 \\
\hline $\mathrm{FeO} *^{*}$ & 10.9 & 11.2 & 11.2 & 10.8 & 10.8 & 10.8 & 10.6 & 10.6 & 10.7 & 10.8 & 10.8 & 11.0 & 10.8 & 10.9 & 11.0 \\
\hline $\mathrm{MnO}$ & 0.22 & 0.21 & 0.22 & 0.22 & 0.21 & 0.23 & 0.22 & 0.19 & 0.23 & 0.23 & 0.23 & 0.23 & 0.17 & 0.21 & 0.21 \\
\hline $\mathrm{MgO}$ & 7.55 & 7.50 & 7.51 & 7.81 & 7.75 & 7.76 & 7.65 & 7.68 & 7.57 & 7.57 & 7.66 & 7.60 & 7.75 & 7.60 & 7.55 \\
\hline $\mathrm{CaO}$ & 12.2 & 12.1 & 12.1 & 12.6 & 12.2 & 12.3 & 12.3 & 12.4 & 12.2 & 12.3 & 12.3 & 12.3 & 12.4 & 12.2 & 12.1 \\
\hline $\mathrm{Na}_{2} \mathrm{O}$ & 2.42 & 2.40 & 2.43 & 2.34 & 2.41 & 2.45 & 2.43 & 2.42 & 2.34 & 2.36 & 2.41 & 2.44 & 2.26 & 2.38 & 2.35 \\
\hline $\mathrm{K}_{2} \mathrm{O}$ & 0.10 & 0.10 & 0.10 & 0.09 & 0.10 & 0.09 & 0.11 & 0.09 & 0.09 & 0.09 & 0.09 & 0.08 & 0.12 & 0.09 & 0.11 \\
\hline Total & 99.5 & 99.6 & 99.0 & 100.1 & 99.5 & 99.6 & 99.2 & 99.3 & 98.8 & 98.9 & 99.4 & 99.4 & 99.0 & 99.5 & 99.2 \\
\hline Or & 0.61 & 0.60 & 0.59 & 0.57 & 0.60 & 0.59 & 0.66 & 0.56 & 0.56 & 0.55 & 0.59 & 0.53 & 0.72 & 0.56 & 0.67 \\
\hline $\mathrm{Ab}$ & 20.5 & 20.4 & 20.6 & 19.9 & 20.4 & 20.8 & 20.6 & 20.5 & 19.9 & 20.0 & 20.4 & 20.7 & 19.2 & 20.2 & 19.9 \\
\hline An & 27.8 & 28.3 & 27.7 & 29.8 & 28.2 & 28.5 & 28.5 & 28.0 & 28.6 & 28.0 & 28.6 & 28.1 & 28.7 & 28.6 & 28.3 \\
\hline $\mathrm{Di}$ & 27.0 & 26.1 & 26.6 & 26.7 & 26.5 & 26.8 & 26.7 & 27.6 & 26.0 & 26.9 & 26.7 & 26.9 & 26.9 & 26.2 & 26.2 \\
\hline $\mathrm{Hy}$ & 14.9 & 15.4 & 13.2 & 11.9 & 14.4 & 11.9 & 12.8 & 12.8 & 15.8 & 15.2 & 12.7 & 13.0 & 14.4 & 15.4 & 16.0 \\
\hline ol & 4.04 & 4.12 & 5.67 & 6.71 & 4.87 & 6.64 & 5.57 & 5.35 & 3.65 & 3.83 & 5.92 & 5.64 & 4.75 & 3.96 & 3.72 \\
\hline $\mathrm{Mt}_{\mathrm{t}}$ & 1.76 & 1.80 & 1.81 & 1.74 & 1.74 & 1.74 & 1.70 & 1.71 & 1.73 & 1.73 & 1.75 & 1.77 & 1.74 & 1.76 & 1.78 \\
\hline II & 2.98 & 3.01 & 3.01 & 2.95 & 2.94 & 2.82 & 2.80 & 2.83 & 2.82 & 2.85 & 2.92 & 2.94 & 2.84 & 3.07 & 2.94 \\
\hline
\end{tabular}

TABLE 2 - Continued

\begin{tabular}{|c|c|c|c|c|c|c|c|c|c|c|c|c|c|c|c|}
\hline \multirow{3}{*}{$\begin{array}{c}\text { Unit } \\
\begin{array}{c}\text { Sample } \\
\text { (Interval in } \mathrm{cm} \text { ) }\end{array} \\
\mathrm{SiO}_{2}\end{array}$} & 2 & 4 & \multicolumn{3}{|c|}{4} & 4 & \multicolumn{2}{|r|}{4} & \multirow{2}{*}{$\frac{4}{40-2,100-106}$} & \multirow{2}{*}{$\frac{7}{43-5,126-132}$} & \multirow{2}{*}{$\frac{9 D}{63-4,131-132}$} & \multirow{2}{*}{$\frac{11}{66-5,94-95}$} & \multicolumn{3}{|c|}{ Interlaboratory Standard ${ }^{a}$} \\
\hline & $31-4,13-17$ & $35-5,84-91$ & & $35-6,112$ & & $36-5,15-22$ & & $1,54-60$ & & & & & & & \\
\hline & 49.8 & 50.3 & 49.8 & 49.8 & 50.5 & 50.1 & 50.0 & 49.8 & 49.8 & 50.0 & 50.1 & 49.7 & 51.5 & 51.5 & 51.9 \\
\hline $\mathrm{TiO}_{2}$ & 1.53 & 1.63 & 1.63 & 1.64 & 1.65 & 1.59 & 1.65 & 1.66 & 1.64 & 1.72 & 1.60 & 1.52 & 1.25 & 1.26 & 1.34 \\
\hline $\mathrm{Al}_{2} \mathrm{O}_{3}$ & 14.5 & 14.3 & 14.3 & 14.1 & 14.2 & 14.2 & 14.0 & 14.2 & 13.9 & 13.6 & 14.1 & 14.4 & 15.6 & 15.4 & 15.6 \\
\hline $\mathrm{FeO}^{*}$ & 11.0 & 11.4 & 11.4 & 11.4 & 11.3 & 11.2 & 11.4 & 11.5 & 11.2 & 11.5 & 11.4 & 11.0 & 9.00 & 8.95 & 9.04 \\
\hline $\mathrm{MnO}$ & 0.22 & 0.20 & 0.22 & 0.22 & 0.16 & 0.21 & 0.22 & 0.14 & 0.24 & 0.21 & 0.21 & 0.22 & 0.12 & 0.15 & 0.15 \\
\hline $\mathrm{MgO}$ & 7.65 & 7.35 & 7.51 & 7.46 & 7.46 & 7.26 & 7.30 & 7.43 & 7.34 & 7.36 & 8.31 & 8.36 & 8.19 & 8.04 & 8.18 \\
\hline $\mathrm{CaO}$ & 12.3 & 12.3 & 12.3 & 12.3 & 12.3 & 12.2 & 12.4 & 12.3 & 12.4 & 12.3 & 12,2 & 12.2 & 12.0 & 11.9 & 12.0 \\
\hline $\mathrm{Na}_{2} \mathrm{O}$ & 2.39 & 2.35 & 2.32 & 2.33 & 2.29 & 2.37 & 2.33 & 2.42 & 2.36 & 2.36 & 2.36 & 2.44 & 2.61 & 2.52 & 2.69 \\
\hline $\mathrm{K}_{2} \mathrm{O}$ & 0.10 & 0.11 & 0.11 & 0.11 & 0.11 & 0.11 & 0.10 & 0.10 & 0.10 & 0.10 & 0.11 & 0.11 & 0.10 & 0.09 & 0.11 \\
\hline Total & 99.4 & 99.9 & 99.5 & 99.3 & 100.0 & 99.3 & 99.3 & 99.5 & 99.0 & 99.1 & 100.4 & 99.9 & 100.4 & 99.7 & 101.0 \\
\hline Or & 0.63 & 0.66 & 0.68 & 0.67 & 0.66 & 0.66 & 0.64 & 0.63 & 0.61 & 0.61 & 0.67 & 0.67 & 0.60 & 0.51 & 0.63 \\
\hline $\mathrm{Ab}$ & 20.2 & 19.9 & 19.7 & 19.7 & 19.4 & 20.1 & 19.8 & 20.5 & 20.0 & 20.0 & 20.0 & 20.7 & 22.1 & 21.4 & 22.7 \\
\hline An & 28.5 & 28.0 & 28.3 & 27.6 & 28.2 & 27.9 & 27.3 & 27.4 & 27.0 & 26.1 & 27.5 & 27.9 & 30.6 & 30.4 & 30.2 \\
\hline $\mathrm{Di}$ & 26.5 & 27.1 & 26.8 & 27.6 & 27.2 & 27.0 & 28.0 & 27.8 & 28.5 & 28.6 & 26.8 & 26.8 & 23.4 & 23.2 & 23.7 \\
\hline Hy & 13.3 & 16.6 & 14.6 & 14.8 & 18.2 & 16.2 & 15.7 & 12.8 & 14.1 & 16.1 & 13.7 & 9.95 & 16.5 & 19.5 & 16.7 \\
\hline OI & 5.77 & 2.81 & 4.73 & 4.16 & 1.67 & 2.78 & 3.06 & 5.48 & 3.98 & 2.69 & 6.86 & 9.35 & 3.39 & 1.00 & 3.13 \\
\hline Mt & 1.78 & 1.84 & 1.84 & 1.84 & 1.82 & 1.81 & 1.84 & 1.85 & 1.81 & 1.86 & 1.84 & 1.77 & 1.45 & 1.44 & 1.46 \\
\hline II & 2.92 & 3.10 & 3.10 & 3.12 & 3.14 & 3.03 & 3.14 & 3.17 & 3.12 & 3.28 & 3.05 & 2.90 & 2.37 & 2.40 & 2.54 \\
\hline
\end{tabular}

WHOL No. All 93-11-5 (dredge sample from $24^{\circ} 58.85^{\prime} \mathrm{S}, 70^{\circ} 00.71^{\prime} \mathrm{E}$ ).

Note: Norms are calculated assuming $\mathrm{Fe}^{3+} /\left(\mathrm{Fe}^{3+}+\mathrm{Fe}^{2+}\right)=0.1$ (atomic ratio) 

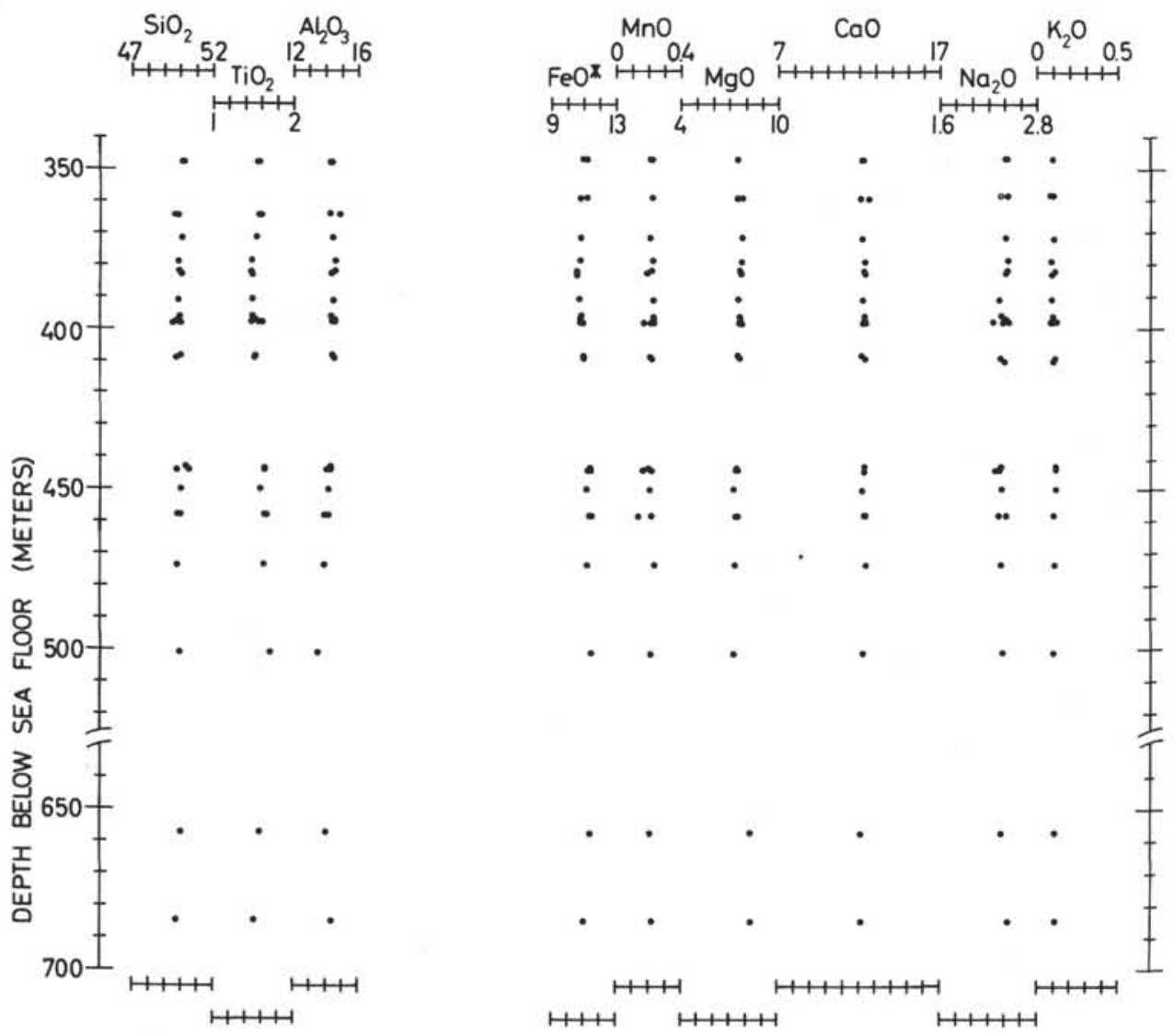

Figure 5. Oxide compositions in wt. \% versus depth for basaltic glass from Hole 417D.

\section{PHASE CHEMISTRY}

Plagioclase, clinopyroxene, olivine, magnetite, and ilmenite were analyzed in 34 polished sections from Hole 417D and in two thin sections from Hole 417 A. Most of the analyses of plagioclase were made partially for $\mathrm{Ca}-\mathrm{Na}-\mathrm{Fe}$ or $\mathrm{Ca}-\mathrm{Na}-\mathrm{K}$. A few grains were analyzed for the following six components: $\mathrm{Si}, \mathrm{Al}, \mathrm{Fe}, \mathrm{Ca}, \mathrm{Na}$, and $\mathrm{K}$. Clinopyroxenes were analyzed partially for three components - $\mathrm{Ca}, \mathrm{Mg}$, and $\mathrm{Fe}$. Some clinopyroxene grains were analyzed for 10 elements, namely $\mathrm{Si}, \mathrm{Ti}, \mathrm{Al}, \mathrm{Cr}, \mathrm{Fe}, \mathrm{Mn}, \mathrm{Mg}, \mathrm{Ca}, \mathrm{Ni}$, and $\mathrm{Na}$. Clinopyroxene was present in all but three of the 36 analyzed thin sections. More than 50 points including phenocryst cores and rims, microphenocrysts, and groundmass, if present, were analyzed in each sample. Olivine occurs as pseudomorphs in most samples, and analyses were possible only for seven sections. Analyses of olivine in most cases were made partially for $\mathrm{Fe}$ and $\mathrm{Mg}$, but complete data, including $\mathrm{Si}, \mathrm{Ti}, \mathrm{Al}, \mathrm{Cr}, \mathrm{Fe}, \mathrm{Mn}, \mathrm{Mg}, \mathrm{Ni}$, and $\mathrm{Na}$ were obtained for some grains. The opaque minerals in the groundmass were generally too small for microprobe analysis even in the centers of pillows. Partial analyses of $\mathrm{Fe}, \mathrm{Ti}$, and $\mathrm{Al}$ in the opaques were thus made in only four samples.

\section{Plagioclase}

The results of six component analyses for plagioclase are listed in Table 3. The mean and standard deviation for $\mathrm{Ca}$, $\mathrm{Na}$, and $\mathrm{Fe}$ shown in Table 4 were calculated using all available data. Calculations were made unit by unit as pro- posed in Figure 6 and also for all data from Hole 417A and for all Leg 52 samples. In Figure 7, the analytical data for plagioclase from aphyric basalts found locally between 435 and 491 meters sub-bottom are given separately. Histograms for the massive basalts ( 413 to $435 \mathrm{~m}$ and 495 to $501 \mathrm{~m}$ sub-bottom) are not shown in Figure 7, since $\mathrm{FeO}^{*}$ was not determined for these units. From the data, the following conclusions may be reached:

1) The range of wt. \% $\mathrm{FeO}^{*}$ in the cores of the plagioclase phenocrysts is slightly different in each pillowed flow (Figure 8). The ranges are 0.3 per cent to 0.7 per cent for the basalts from Hole 417A and for the basalts recovered between 343 and 365 meters and 365 and 397 meters in Hole 417D; 0.4 per cent to 0.8 per cent for the basalts in Hole 417D between 397 and 413 meters, 435 and 491 meters, and 491 and 495 meters and for basalts recovered in the same hole on Leg 52; and 0.5 per cent to 0.9 per cent for the basalts from 501 to 532 meters in Hole 417D. Two types of $\mathrm{An}-\mathrm{FeO}^{*}$ variation during the progressive stages of crystallization are identified in Figure 8. Weight percentage of $\mathrm{FeO}^{*}$ increases with decreasing $\mathrm{An} / \mathrm{Ab}+\mathrm{An}$. The groundmass of the basalts recovered between 343 and 365 meters, 365 and 397 meters, and 435 and 491 meters in Hole 417D, as well as those recovered in Hole 417A and on Leg 52 from Hole 417D, shows higher rates of increase of $\mathrm{FeO}^{*}$ with decreasing An. This trend is discontinuous with that of the phenocrysts. On the other hand, the data for the pillow lavas from 491 to 495 meters and 501 to 532 meters in Hole 417D show continuous increase in $\mathrm{FeO}^{*}$ throughout 


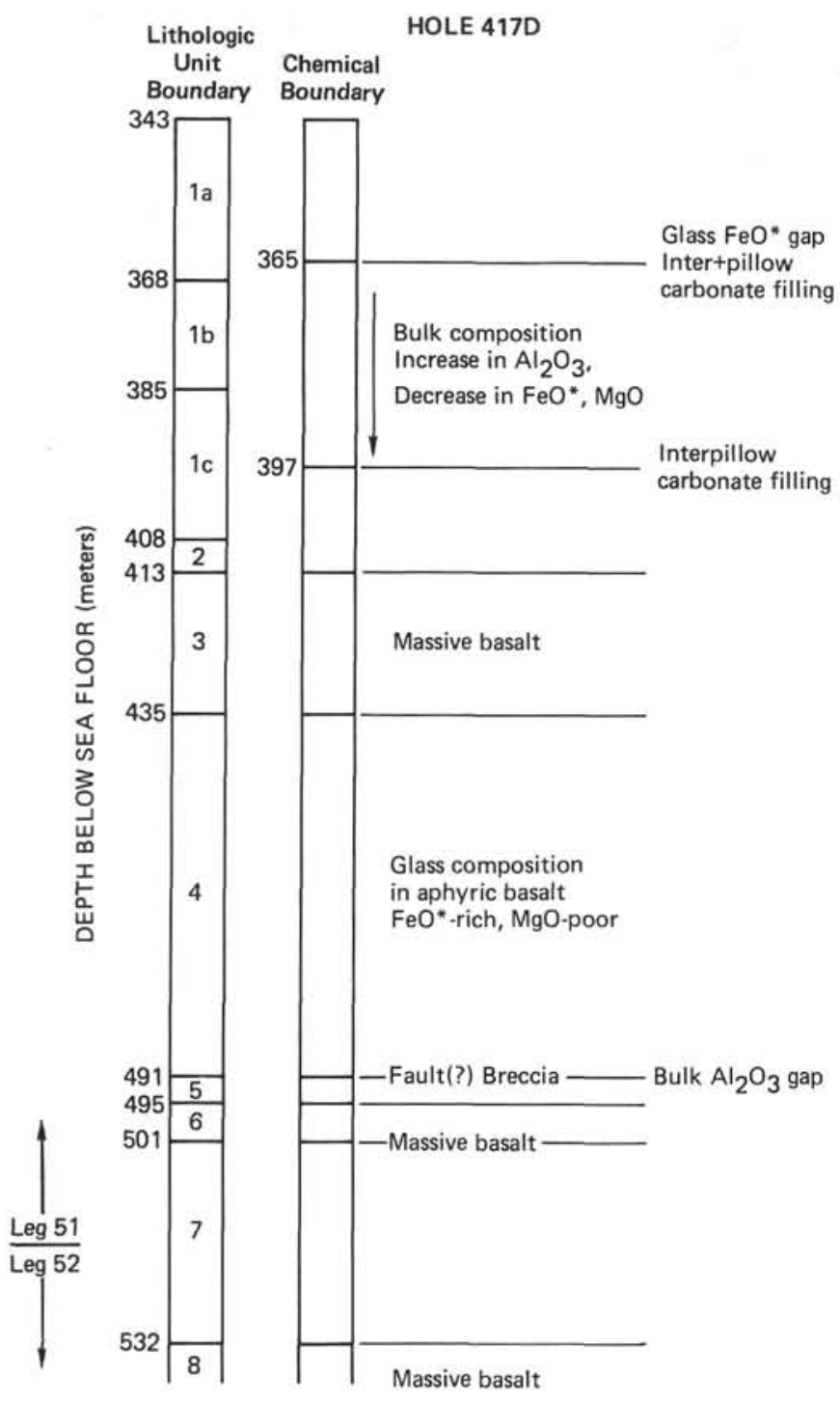

Figure 6. Preliminary lithologic unit boundaries based on shipboard analysis; revised boundaries based on chemistry and texture (this study).

all stages of crystallization (Figure 8). The maximum $\mathrm{FeO}^{*}$ content in the groundmass is about 1.5 per cent for all units.

2) The plagioclase An content ranges between 64 per cent and 94 per cent in the basalts recovered in Hole 417D from the 343 to 365 meter, 365 to 397 meter, 397 to 413 meter, and 435 to 491 meter intervals, ranging between 68 per cent and 86 per cent for the basalts from the 491 to 495 meter and 501 to 532 meter intervals (Figure 7). Those in the groundmass range between 52 per cent and 76 per cent in the former units and between 46 per cent and 74 per cent in the latter. The mean $\mathrm{CaO}$ content of the phenocrysts for both groups is 16.9 per cent to 17.4 per cent and 15.6 per cent to 15.7 per cent, respectively, while that of groundmass for both groups is 13.8 per cent to 14.0 per cent and 12.9 per cent to 13.5 per cent, respectively. The change at the 491 meter depth is consistent with the change in bulk rock composition mentioned previously. The An content of Hole $417 \mathrm{~A}$ is similar to that of the former group (shallower than $491 \mathrm{~m}$ sub-bottom) but Ca-richer in groundmass.
TABLE 3

Average Plagioclase Compositions for Hole 417D Basalts

\begin{tabular}{|c|c|c|c|c|}
\hline & \multicolumn{2}{|c|}{ 343-491 Meters Sub-Bottom } & \multicolumn{2}{|c|}{$\begin{array}{l}\text { Sparsely Phyric to Aphyrio } \\
\text { Basalts Between } 435-491 \\
\text { Meters Sub-Bottom }\end{array}$} \\
\hline & $\begin{array}{l}\text { Phenocryst } \\
\text { Cores }\end{array}$ & Groundmass & $\begin{array}{l}\text { Phenocryst } \\
\text { Cores }\end{array}$ & Groundmass \\
\hline $\begin{array}{l}\text { No. of } \\
\text { Analyses }\end{array}$ & 7 & 4 & 8 & 4 \\
\hline $\mathrm{SiO}_{2}$ & 47.6 & 51.0 & 48.2 & 52.1 \\
\hline $\mathrm{Al}_{2} \mathrm{O}_{3}$ & 31.7 & 28.9 & 30.7 & 27.7 \\
\hline $\mathrm{FeO}^{*}$ & 0.66 & 1.28 & 0.66 & 1.07 \\
\hline $\mathrm{CaO}$ & 17.0 & 13.6 & 16.3 & 13.2 \\
\hline $\mathrm{Na}_{2} \mathrm{O}$ & 2.26 & 3.66 & 2.57 & 4.04 \\
\hline $\mathrm{K}_{2} \mathrm{O}$ & 0.01 & 0.01 & 0.00 & 0.03 \\
\hline Total & 99.2 & 98.5 & 98.4 & 98.2 \\
\hline \multicolumn{5}{|c|}{ Number of ions assuming $\mathrm{O}=32$} \\
\hline $\mathrm{Si}$ & 8.846 & 9.473 & 9.014 & 9.679 \\
\hline Al & 6.945 & 6.322 & 6.760 & 6.071 \\
\hline $\mathrm{Fe}$ & 0.104 & 0.199 & 0.104 & 0.167 \\
\hline $\mathrm{Ca}$ & 3.379 & 2.710 & 3.261 & 2.637 \\
\hline $\mathrm{Na}$ & 0.817 & 1.312 & 0.933 & 1.458 \\
\hline $\mathrm{K}$ & 0.000 & 0.001 & 0.000 & 0.001 \\
\hline
\end{tabular}

3) The range of An percentage in the massive basalts is wider than that in the pillow basalts. This is presumably caused by slower cooling and greater in situ fractional crystallization. The maximum An percentage in the massive basalts is similar to that in the surrounding pillow flows.

\section{Clinopyroxene}

Results of total and partial analyses of clinopyroxene are shown in Tables 5 and 6. Phenocryst compositions generally lie within the compositional fields of Ca-rich endiopside and $\mathrm{Fe}$-poor augite as defined by Poldervaart and Hess (1951) (Figure 9). Slight differences, particularly in the Fs content, are found in the section. For example, the clinopyroxene phenocrysts in the pillow lavas between 491 and 495 meters and 501 and 532 sub-bottom and the massive basalts between 495 and 501 meters sub-bottom are slightly enriched in Fs, while those from the aphyric basalts from the 413 to 491 meter interval show the highest enrichment in Fs observed in the section. The groundmass compositions lie for the most part within the augite field but also extend into the fields for salite, ferrosalite, and ferroaugite. Pigeonitic clinopyroxene was not found in our samples.

\section{Olivine}

The olivine compositional range is Fan-26 (Tables 7 and 8 , Figure 10 ). The microphenocrysts are slightly enriched in $\mathrm{FeO}^{*}$. Compositional zoning was not found. The data are insufficient to define compositional changes between units. Some of the analyzed grains within the chilled glassy rims are about the size of the groundmass phase $(<0.1 \mathrm{~mm}$ across). However, these grains are euhedral and probably were not formed during crystallization of the groundmass but crystallized prior to eruption. Fresh groundmass olivine was not found in the pillow interiors. 
TABLE 4

Averages of Partial Analyses of Plagioclase From Hole 417A and 417D Basalts

\begin{tabular}{|c|c|c|c|c|c|c|c|c|c|c|c|}
\hline & $\begin{array}{l}\text { Hole 417A } \\
\text { Pillow Lava }\end{array}$ & $\begin{array}{l}343-365 \mathrm{~m} \\
\text { Pillow Lava }\end{array}$ & $\begin{array}{l}365-397 \mathrm{~m} \\
\text { Pillow Lava }\end{array}$ & $\begin{array}{l}397-413 \mathrm{~m} \\
\text { Pillow Lava }\end{array}$ & $\begin{array}{c}413-435 \mathrm{~m} \\
\text { Massive Flow }\end{array}$ & $\begin{array}{l}\text { Hole 417D } \\
435-491 \mathrm{~m} \\
\text { Pillow Lava }\end{array}$ & $\begin{array}{c}435-491 \mathrm{~m} \\
\text { Aphyric Basalt }\end{array}$ & $\begin{array}{l}491-495 \mathrm{~m} \\
\text { Pillow Lava }\end{array}$ & $\begin{array}{c}495-501 \mathrm{~m} \\
\text { Massive Flow }\end{array}$ & $\begin{array}{l}501-532 \mathrm{~m} \\
\text { Pillow Lava }\end{array}$ & $\begin{array}{l}\text { Leg 52, } \\
\text { Hole 417D }\end{array}$ \\
\hline & \multicolumn{10}{|c|}{ Phenocryst Cores } & \\
\hline No. of Analyses & 35 & 41 & 141 & 53 & 428 & 99 & 50 & 39 & 129 & 17 & 42 \\
\hline $\begin{array}{l}\mathrm{FeO} * \\
\mathrm{CaO}^{*} \\
\mathrm{Na}_{2} \mathrm{O}\end{array}$ & $\begin{aligned} 0.54 & \pm 0.11 \\
17.3 & \pm 0.9 \\
2.16 & \pm 0.45\end{aligned}$ & $\begin{array}{c}0.56 \pm 0.19 \\
17.0 \pm 1.5 \\
2.28 \pm 0.83\end{array}$ & $\begin{aligned} 0.53 & \pm 0.11 \\
17.1 & \pm 1.2 \\
2.07 & \pm 0.68\end{aligned}$ & $\begin{aligned} 0.57 & \pm 0.13 \\
17.4 & \pm 0.9 \\
1.97 & \pm 0.51\end{aligned}$ & $\begin{aligned} 14.8 & \pm 2.2 \\
2.68 & =1.23\end{aligned}$ & $\begin{array}{c}0.60 \pm 0.15 \\
16.9 \pm 1.3 \\
2.24 \pm 0.69\end{array}$ & $\begin{array}{c}0.78 \pm 0.21 \\
15.2 \pm 1.4 \\
3.29 \pm 0.79\end{array}$ & $\begin{array}{c}0.62 \pm 0.12 \\
15.7 \pm 0.9 \\
2.90 \pm 0.46\end{array}$ & $\begin{array}{c}15.3 \stackrel{-}{ } \pm 1.7 \\
3.01 \pm 0.75\end{array}$ & $\begin{array}{c}0.76 \pm 0.12 \\
15.6 \pm 0.9 \\
2.94 \pm 0.48\end{array}$ & $\begin{aligned} 0.70 & \pm 0.16 \\
16.3 & \pm 1.2 \\
2.66 & \pm 0.62\end{aligned}$ \\
\hline $\mathrm{Na}_{2} \mathrm{O}$ & \multicolumn{10}{|c|}{ Phenocryst Rims and Microphenocrysts } & \\
\hline No. of Analyses & 14 & 27 & 70 & 7 & - & 52 & 53 & 29 & - & 11 & 32 \\
\hline $\begin{array}{l}\mathrm{FeO} * \\
\mathrm{CaO} \\
\mathrm{Na}_{2} \mathrm{O}\end{array}$ & $\begin{aligned} 0.80 & \pm 0.28 \\
15.8 & \pm 2.0 \\
2.86 & \pm 1.08\end{aligned}$ & $\begin{aligned} 0.86 & \pm 0.22 \\
14.9 & \pm 1.5 \\
3.32 & \pm 0.78\end{aligned}$ & $\begin{aligned} 0.81 & \pm 0.20 \\
15.4 & \pm 1.5 \\
3.05 & \pm 0.80\end{aligned}$ & $\begin{aligned} 0.71 & \pm 0.09 \\
15.8 & \pm 1.2 \\
2.71 & \pm 0.56\end{aligned}$ & $\bar{z}$ & $\begin{aligned} 0.83 & \pm 0.26 \\
15.0 & \pm 1.0 \\
3.26 & \pm 0.57\end{aligned}$ & $\begin{aligned} 0.96 & \pm 0.16 \\
13.8 & =1.6 \\
4.03 & \pm 0.87\end{aligned}$ & $\begin{aligned} 0.79 & \pm 0.15 \\
14.9 & \pm 0.7 \\
3.29 & \neq 0.37\end{aligned}$ & $\overline{-}$ & $\begin{aligned} 1.04 & \pm 0.12 \\
14.0 & \pm 1.0 \\
3.85 & \pm 0.58\end{aligned}$ & $\begin{aligned} 1.01 & \pm 0.22 \\
14.5 & \pm 1.3 \\
3.68 & \pm 0.70\end{aligned}$ \\
\hline $\mathrm{Na}_{2} \mathrm{O}$ & \multicolumn{10}{|c|}{ Groundmass } & \\
\hline No. of Analyses & 44 & 69 & 79 & - & - & 52 & 49 & 40 & - & 24 & 88 \\
\hline $\begin{array}{l}\mathrm{FeO}^{*} \\
\mathrm{CaO} \\
\mathrm{Na}_{2} \mathrm{O}\end{array}$ & $\begin{aligned} 1.04 & =0.28 \\
14.7 & =1.3 \\
3.55 & =0.75\end{aligned}$ & $\begin{aligned} 1.03 & \pm 0.20 \\
14.0 & \pm 0.8 \\
3.79 & \pm 0.43\end{aligned}$ & $\begin{aligned} 1.03 & \pm 0.22 \\
13.8 & \pm 0.9 \\
3.85 & \pm 0.47\end{aligned}$ & $\bar{z}$ & $\bar{z}$ & $\begin{array}{c}1.07 \pm 0.28 \\
13.9 \pm 0.8 \\
3.85 \pm 0.42\end{array}$ & $\begin{aligned} 1.25 & \pm 0.36 \\
13.3 & =1.4 \\
4.29 & \pm 0.73\end{aligned}$ & $\begin{array}{c}1.21 \pm 0.28 \\
12.9 \pm 1.5 \\
4.44 \pm 0.74\end{array}$ & $\overline{-}$ & $\begin{array}{c}1.15 \pm 0.21 \\
13.5 \pm 1.2 \\
4.13 \pm 0.64\end{array}$ & $\begin{aligned} 1.28 & \pm 0.24 \\
13.4 & \pm 1.2 \\
4.22 & \pm 0.62\end{aligned}$ \\
\hline
\end{tabular}

\section{Opaque Minerals}

Opaque minerals usually occur as quenched dendritic crystals, except in the chilled glassy margins where no groundmass phase was found. Generally, the grains were not large enough for microprobe analysis. Probe data were available from only four samples (Table 9). Most of the oxide phases are considered to be titanomagnetite, but it was difficult to obtain precise results because of compositional zoning and the small size of the grains. Another Tirich, Fe-poor oxide phase was found in Samples 417D-29-6, $34-42 \mathrm{~cm}, 417 \mathrm{D}-39-3,18-24 \mathrm{~cm}$, and 417D-45-1, 138$144 \mathrm{~cm}$. This phase is probably ilmenite, but the grain size was too small for accurate geochemical identification (Table 9).

\section{DISCUSSION}

\section{Comparison With the Chemistry of Basalts From the Present Mid-Atlantic Ridge}

The bulk chemical data presented above are compared with data from $25^{\circ} \mathrm{N}$ and $30^{\circ} \mathrm{N}$ on the Mid-Atlantic Ridge (Miyashiro et al., 1969; Shido et al., 1974) and Leg 46 (Sato et al., 1978) in Figure 11 and the glass data are compared with those from the FAMOUS area (Bryan and Moore, 1977) and Leg 46 (Sato et al., 1978) in Figure 12. As can be seen in Figure 11, the compositions of the Hole 417D samples are poorer in $\mathrm{SiO}_{2}, \mathrm{MgO}, \mathrm{Na}_{2} \mathrm{O}$, and $\mathrm{K}_{2} \mathrm{O}$ than samples from the present Mid-Atlantic Ridge, the averaged differences being approximately $3.0,1.0,0.5$ and 0.05 per cent, respectively. On the other hand, $\mathrm{CaO}$ is higher by 1 per cent and the $\mathrm{FeO} * / \mathrm{MgO}$ ratio is also higher (1.3 to 1.7) except in Sample 417D-41-7, 80-86 cm (Analysis 22, Table 1) which has an $\mathrm{FeO} * / \mathrm{MgO}$ ratio of 0.8 because of an accumulation of mafic phenocrysts. The $\mathrm{FeO} * / \mathrm{MgO}$ ratio for glasses from Hole 417D ranges between 1.3 and 1.6 and is higher than that for samples from Leg 46 and the FAMOUS area (Figure 12). All data points, except for two points on the $\mathrm{FeO}^{*}$ and $\mathrm{MgO}$ diagrams, fit along a simple variation trend. These two isolated points represent samples from the deeper levels of Hole 417D drilled on Leg 52. The $\mathrm{SiO}_{2}, \mathrm{Na}_{2} \mathrm{O}$, and $\mathrm{K}_{2} \mathrm{O}$ contents are depleted slightly in the Hole 417D samples compared with the gen- eral trend for glass from the FAMOUS area and Leg 46; on the other hand, $\mathrm{CaO}$ is enriched (Figure 12). Both the glass and bulk rock data show similar enrichment or depletion trends. This argument neglects the possibility that alteration is responsible for the compositional differences observed between the Hole 417D rocks and rocks from the presentday Mid-Atlantic Ridge. The range of $\mathrm{FeO}^{*} / \mathrm{MgO}$ is large enough to be due to differences in the degree of fractionation, but smaller than that observed in samples from the FAMOUS area and Leg 46 . The iron-rich samples come from intervals deeper than 435 meters, suggesting that the magma emplaced between 435 and 491 meters was slightly fractionated compared with that in the 343 to 413 meter interval. Scattering of the bulk rock data is explained by intrapillow crystal fractionation. Euhedral olivine phenocrysts are common in the Site 417 samples. Usually, olivine is altered and remains only as pseudomorphs, but fresh olivine grains are found in fresh glassy rims. Samples from Cores 40 and 41 preserved fresh olivine even in the crystalline pillow interiors. Both olivine and glass were analyzed in Samples 417D-26-6, 2-10 cm, 417D-28-5, 85-92 cm, 417D-30-4, 95-101 cm, 417D-31-4, 13-17 cm, and 417D$38-1,54-60 \mathrm{~cm}$. Using the geothermometer of Roeder and Emslie (1970), the equilibrium temperatures of these five samples were determined to be slightly higher than $1200^{\circ} \mathrm{C}$ (Figure 13). The temperature for the 365 to 397 meter unit (Mg-rich) is approximately $10^{\circ} \mathrm{C}$ higher than that of the 435 to 491 meter unit (Mg-poor). Data for rocks from the FAMOUS area (Hekinian et al., 1976) are shown in the same diagram for comparison. The Site 417 samples equilibrated at a relatively low temperature compared with the majority of the samples from the FAMOUS area. This trend is consistent with the higher bulk rock $\mathrm{FeO} * / \mathrm{MgO}$ ratio and higher modal phenocryst content observed in the samples from Hole 417D.

\section{Compositional Variation Within the 365 to 397 meter Interval}

Modal and compositional variations within the pillow basalts found between 365 and 397 meters are summarized in Figure 14. As mentioned previously, this interval is considered to consist of one single flow of pillowed lava. Data 

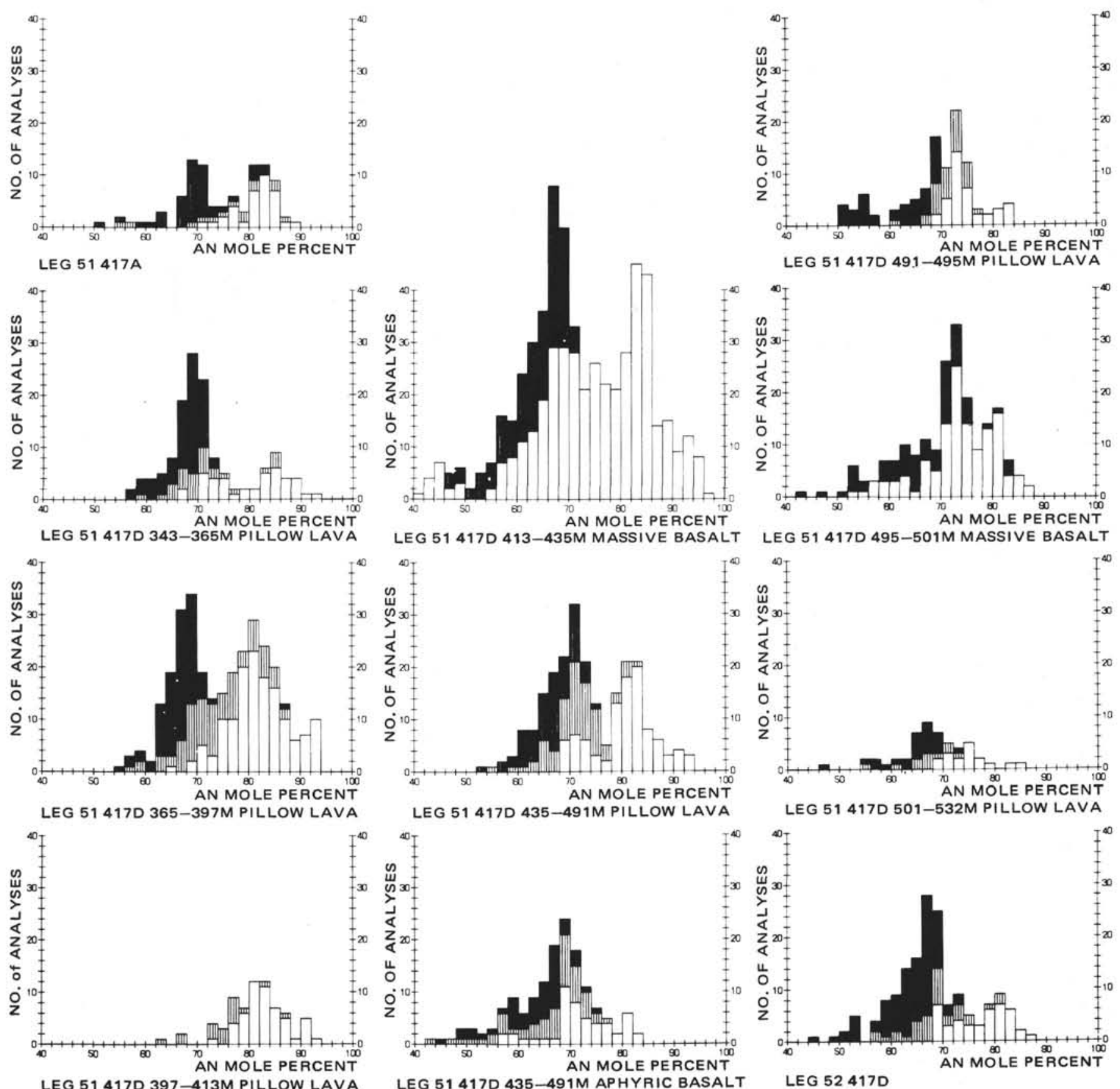

LEG 51 417D 435-491M APHYRIC BASALT

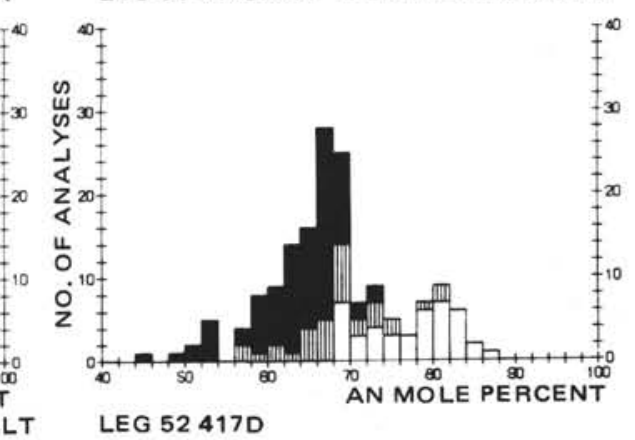

Figure 7. Histograms of plagioclase compositions for Holes $417 \mathrm{~A}$ and $417 \mathrm{D}$. Open bar $=$ phenocryst cores; striped bar $=$ phenocryst rims and microphenocrysts; and heavily striped bar = groundmass.

points in the diagram are classified into two groups: those from chilled pillow rims and those from pillow interiors. If there is a gradual change in composition or mineralogy within a single flow, it should be detectable in samples collected from various levels of the flow. A sample collected from the lower part of a pillowed flow, for example, should represent an earlier effusive product of volcanic activity, while samples from higher levels should represent later products. Original changes in composition within such a sequence may be obscured by crystal settling during the solidification of each pillow. Chilled pillow margins preserve the original bulk composition and phenocryst min- eralogy. Five bulk rock analyses are available from the 365 to 397 meter interval, but unfortunately all are for samples from pillow interiors. Nonetheless, gradual changes in composition with depth may be seen in Figure 14: $\mathrm{Al}_{2} \mathrm{O}_{3}$ decreases by 1.3 per cent towards the top of the flow, while $\mathrm{FeO}^{*}$ and $\mathrm{MgO}$ increase by 1.7 per cent and 1.3 per cent, respectively, toward the top.

Seven analyses of chilled glass are available from the 365 to 397 meter interval. The variation trend for $\mathrm{Al}_{2} \mathrm{O}_{3}$ is the reverse of that of the bulk data $\left(\mathrm{Al}_{2} \mathrm{O}_{3}\right.$ increases 0.6 per cent toward the top of the unit), while no variation was detected for $\mathrm{FeO}^{*}$ and $\mathrm{MgO}$ increases slightly ( 0.2 per cent) toward 

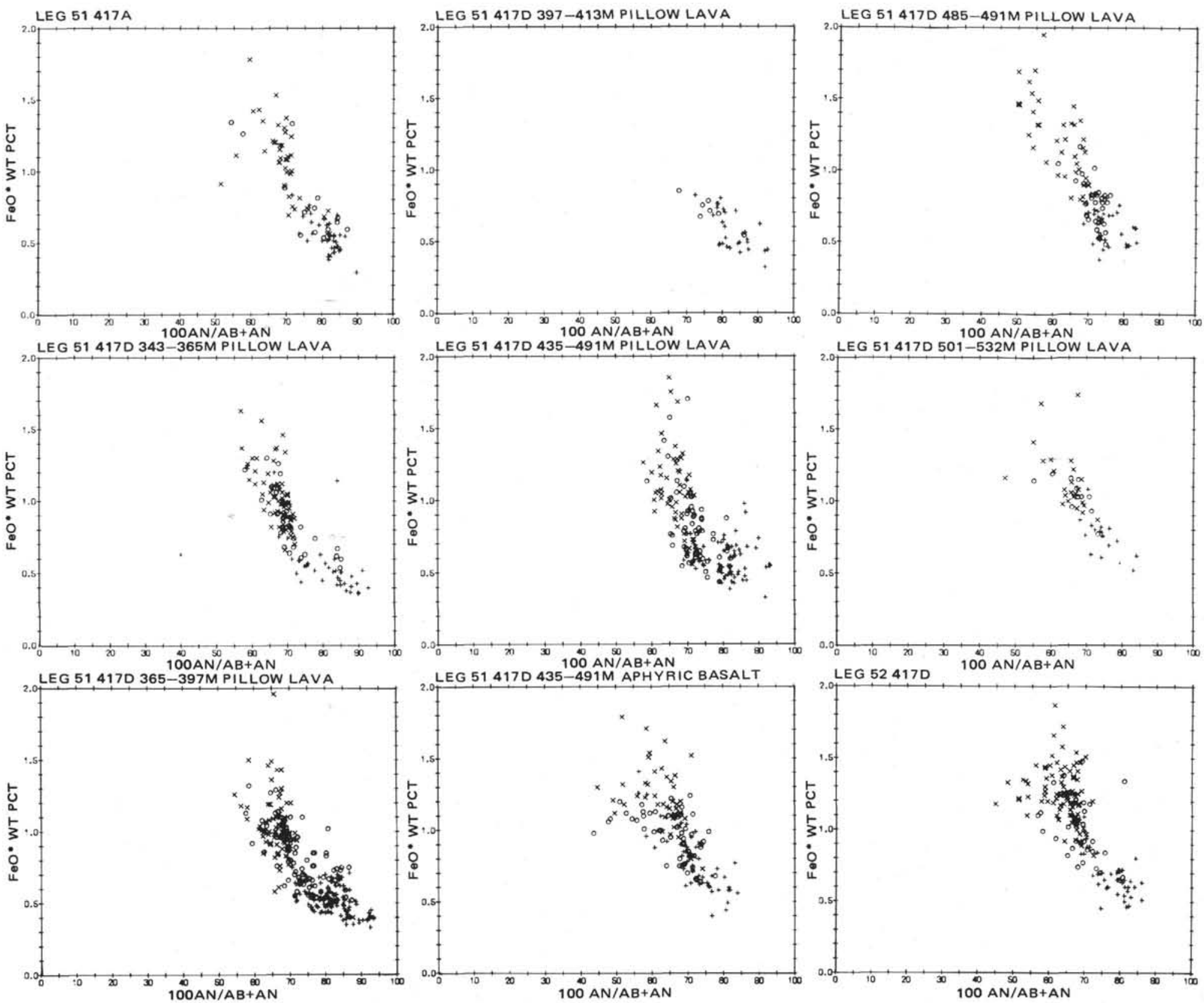

Figure 8. Wt. \% FeO* versus mol. \% An/Ab+An for plagioclase from Holes $417 \mathrm{~A}$ and $417 \mathrm{D}$. Plus $=$ phenocryst cores; circle $=$ phenocryst rim or microphenocryst; and cross $=$ groundmass. 
TABLE 5

Average Clinopyroxene Compositions for Hole 417D Basalts

\begin{tabular}{|c|c|c|}
\hline & $\begin{array}{c}\text { Basalts Between } \\
435-491 \mathrm{~m} \\
\text { Sub-Bottom }\end{array}$ & $\begin{array}{c}\text { Sparsely Phyric to } \\
\text { Aphyric Basalts } \\
\text { Between } 435-491 \mathrm{~m} \\
\text { Sub-Bottom }\end{array}$ \\
\hline & $\begin{array}{l}\text { Phenocryst } \\
\text { Cores }\end{array}$ & $\begin{array}{l}\text { Phenocryst } \\
\text { Cores }\end{array}$ \\
\hline $\begin{array}{l}\text { No. of } \\
\text { Analyses }\end{array}$ & 2 & 4 \\
\hline $\mathrm{SiO}_{2}$ & 52.3 & 51.9 \\
\hline $\mathrm{TiO}_{2}^{2}$ & 0.45 & 0.72 \\
\hline $\mathrm{Al}_{2} \mathrm{O}_{3}$ & 3.23 & 4.06 \\
\hline $\mathrm{FeO}^{*}$ & 5.52 & 8.00 \\
\hline $\mathrm{MnO}$ & 0.18 & 0.23 \\
\hline $\mathrm{MgO}$ & 17.6 & 17.6 \\
\hline $\mathrm{CaO}$ & 21.5 & 19.1 \\
\hline $\mathrm{Na}_{2} \mathrm{O}$ & 0.31 & 0.32 \\
\hline $\mathrm{Cr}_{2} \mathrm{O}_{3}$ & 1.34 & 0.66 \\
\hline $\mathrm{NiO}$ & 0.03 & 0.06 \\
\hline Total & 102.5 & 102.7 \\
\hline \multicolumn{3}{|c|}{ Number of ions assuming $O=6$} \\
\hline $\mathrm{Si}$ & 1.878 & 1.865 \\
\hline $\mathrm{Ti}$ & 0.012 & 0.020 \\
\hline $\mathrm{Al}$ & 0.137 & 0.173 \\
\hline $\mathrm{Cr}$ & 0.039 & 0.019 \\
\hline $\mathrm{Fe}$ & 0.166 & 0.241 \\
\hline $\mathrm{Mn}$ & 0.006 & 0.007 \\
\hline $\mathrm{Mg}$ & 0.945 & 0.945 \\
\hline $\mathrm{Ca}$ & 0.829 & 0.738 \\
\hline $\mathrm{Ni}$ & 0.001 & 0.002 \\
\hline $\mathrm{Na}$ & 0.022 & 0.023 \\
\hline
\end{tabular}

the top. We have prepared thin sections for all 14 samples from this unit and present modal analyses for the samples in Table 10. The plagioclase content of the pillow margins gradually decreases from $18 \mathrm{vol} \%$ at the bottom of the section to 8 vol. \% at the top. Data from the pillow interiors show considerable scatter, but in general, the plagioclase content decreases toward the top of the section (Figure 15). No systematic trend was detected for mafic phenocrysts. The voume of the groundmass at the bottom of the flow is about 80 per cent, but increases towards the top to about 92 per cent.

Most of these gradual modal and chemical variations may be explained quantitatively by a concentration of plagioclase toward the bottom of the flow. This suggests accumulation of plagioclase near the top of the magma reservoir prior to eruption. Floating of plagioclase crystals may occur at depths greater than about $25 \mathrm{~km}$ according to recent measurements of the density of tholeiitic melt at high presures (Fujii and Kushiro, 1978). This model does not however explain the compositional variation of glass mentioned above.

\section{Aphyric Intervals Within Pillow Lavas Between 435 and 491 meters}

Sparsely phyric basalts were recovered locally within the pillowed flows drilled at Site 417. In the case of Hole 417A, such rocks were observed in Sections 26-1 and 26-2, but were difficult to study because of strong alteration. In Hole 417D, aphyric rocks were found in the following intervals:

Section 37-6, 40-55 cm, near the upper margin of a pillow;

Section $38-3,125-145 \mathrm{~cm}$, near the upper margin of a pillow;

Section 38-5, 100-105 cm, near the upper margin of a pillow;

Section 38-6, 50-60 cm, relation to chilled margin unknown;

Section $39-2,90 \mathrm{~cm}$ to Section $39-3,25 \mathrm{~cm}$, starting $5 \mathrm{~cm}$ below the upper margin of a pillow;

Section 39-3, 45-95 cm, in the lower half of the same pillow.

Several features of the aphyric basalts are notable: (1) All aphyric basalts occur within restricted zones between 457 and 468 meters sub-bottom. (2) The thickness of the aphyric zones in the direction of drilling ranges between $10 \mathrm{~cm}$ and $65 \mathrm{~cm}$. (3) Four of the six cases are located near the top of pillows. (4) Two of the aphyric zones are found within a single pillow. (5) The boundary between porphyritic basalt

TABLE 6

Averages of Partial Analyses of Clinopyroxene From Site 417 Basalts

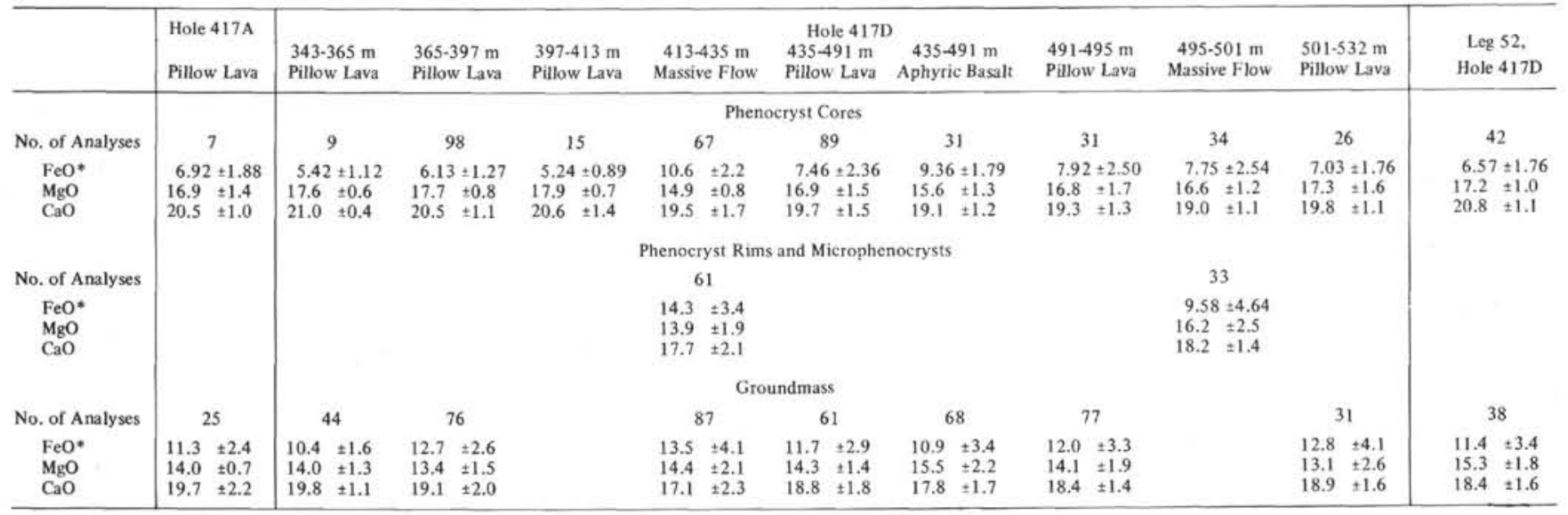



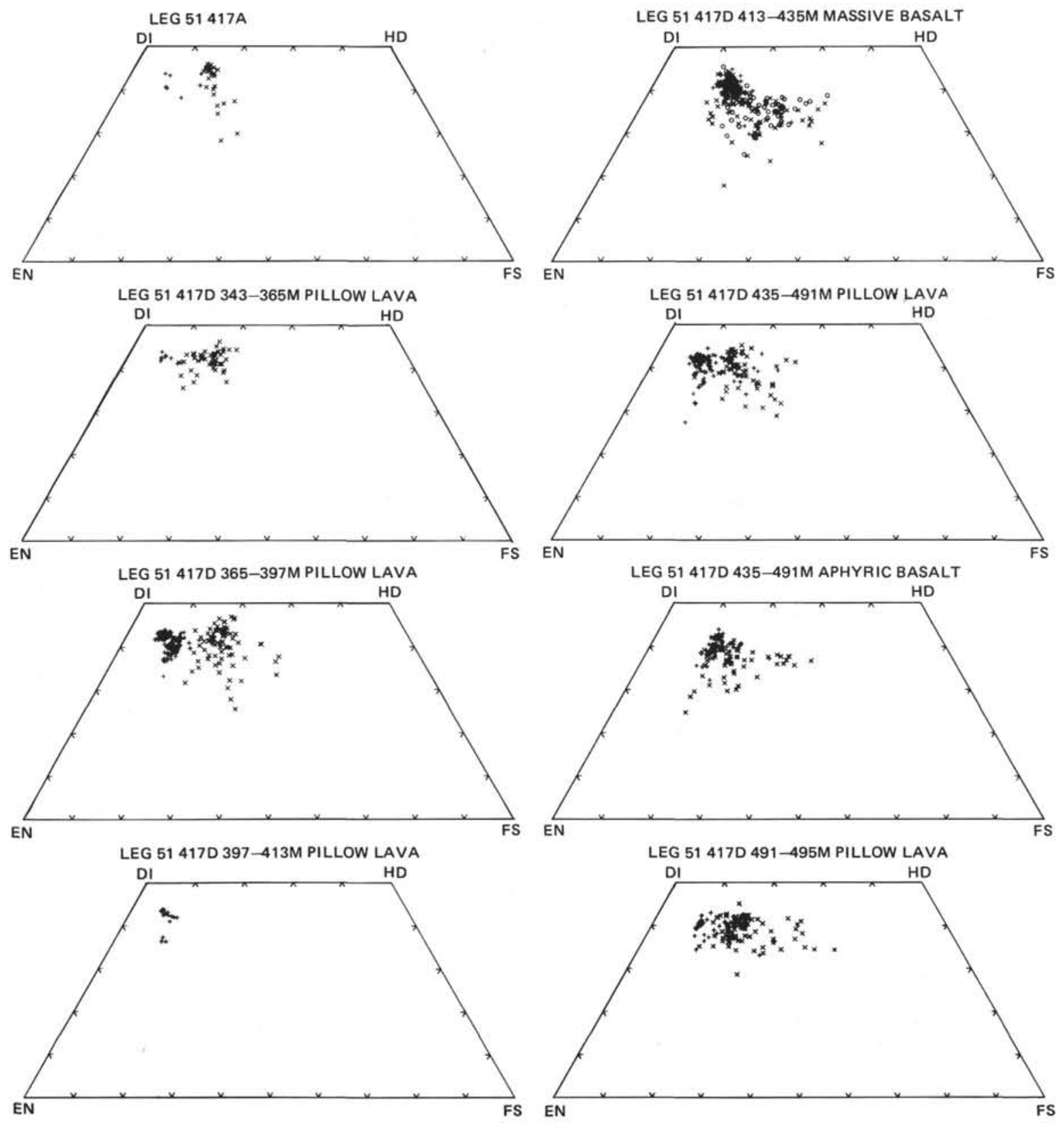

LEG 51 417D 435-491M APHYRIC BASALT
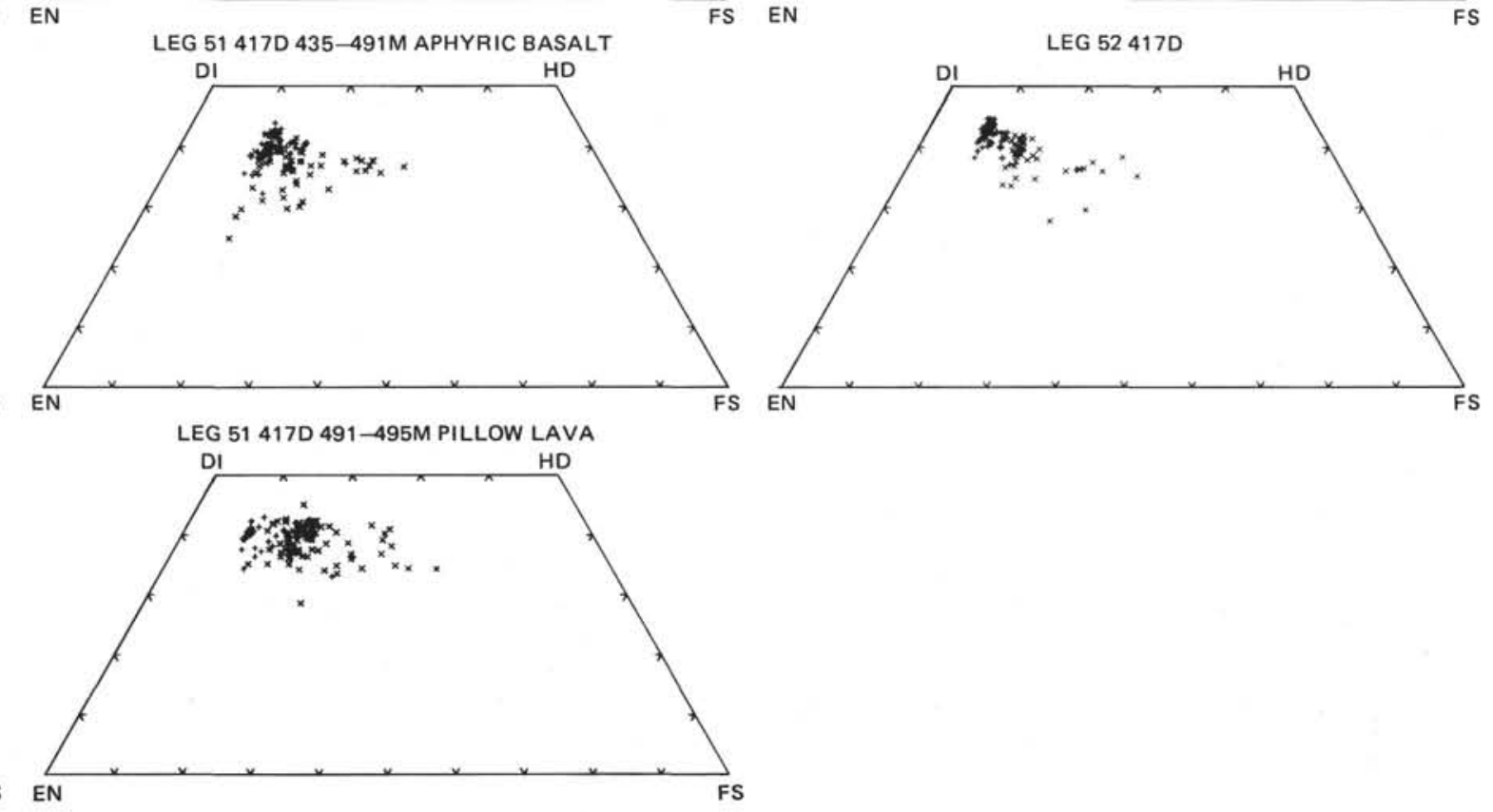
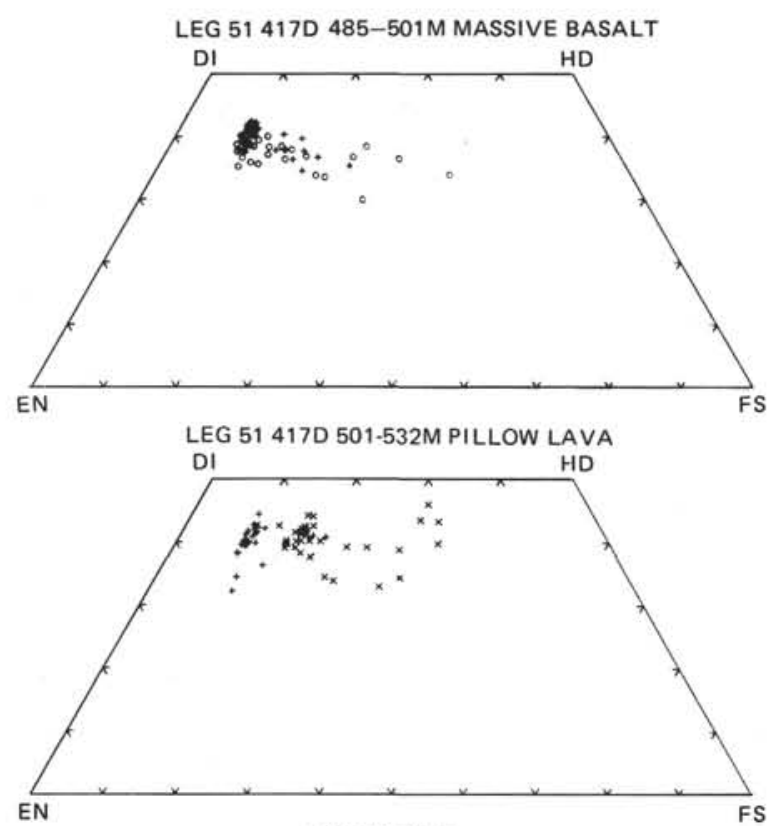
TABLE 7

Average Olivine Compositions for Hole 417D Basalts

\begin{tabular}{|c|c|c|}
\hline & \multicolumn{2}{|c|}{ 343-491 Meters Sub-Bottom } \\
\hline & $\begin{array}{l}\text { Phenocryst } \\
\text { Cores }\end{array}$ & Groundmass \\
\hline $\begin{array}{c}\text { No. of } \\
\text { Analyses }\end{array}$ & 11 & 2 \\
\hline $\mathrm{SiO}_{2}$ & 39.4 & 39.1 \\
\hline $\mathrm{TiO}_{2}$ & 0.01 & 0.02 \\
\hline $\mathrm{Al}_{2} \mathrm{O}_{3}$ & 0.41 & 0.45 \\
\hline $\mathrm{FeO}^{*}$ & 14.8 & 16.2 \\
\hline $\mathrm{MnO}$ & 0.22 & 0.24 \\
\hline $\mathrm{MgO}$ & 45.2 & 43.9 \\
\hline $\mathrm{Na}_{2} \mathrm{O}$ & 0.07 & 0.11 \\
\hline $\mathrm{Cr}_{2} \mathrm{O}_{3}$ & 0.10 & 0.13 \\
\hline $\mathrm{NiO}$ & 0.27 & 0.23 \\
\hline Total & 100.4 & 100.3 \\
\hline \multicolumn{3}{|c|}{ Number of ions assuming $\mathrm{O}=4$} \\
\hline $\mathrm{Si}$ & 0.982 & 0.982 \\
\hline $\mathrm{Ti}$ & 0.000 & 0.001 \\
\hline Al & 0.012 & 0.014 \\
\hline $\mathrm{Cr}$ & 0.002 & 0.003 \\
\hline $\mathrm{Fe}$ & 0.309 & 0.339 \\
\hline $\mathrm{Mn}$ & 0.005 & 0.005 \\
\hline $\mathrm{Mg}$ & 1.678 & 1.640 \\
\hline $\mathrm{Ni}$ & 0.005 & 0.005 \\
\hline $\mathrm{Na}$ & 0.004 & 0.006 \\
\hline
\end{tabular}

TABLE 8

Averages of Partial Analyses of Olivine From Hole 417D Basalts

365-397 m 397-431 m 435-491 m

Pillow Lava Pillow Lava Pillow Lava

\begin{tabular}{cccc}
\hline & \multicolumn{3}{c}{ Phenocryst Cores } \\
No. of Analyses & 13 & 10 & 32 \\
$\mathrm{FeO}^{*}$ & $14.4 \pm 1.0$ & $15.5 \pm 0.8$ & $14.8 \pm 1.9$ \\
$\mathrm{MgO}$ & $44.7 \pm 1.6$ & $44.1 \pm 1.1$ & $44.7 \pm 1.9$ \\
& \multicolumn{4}{c}{} \\
& Phenocryst & Rims and Microphenocrysts \\
No. of Analyses & 1 & 15 & 29 \\
FeO* & 15.1 & $15.5 \pm 1.0$ & $16.0 \pm 1.6$ \\
$\mathrm{MgO}$ & 43.6 & $43.9 \pm 0.9$ & $42.6 \pm 1.8$ \\
\hline
\end{tabular}

and aphyric basalt is often relatively sharp, but is nevertheless hard to trace exactly. No chilled contacts or minor joints suggesting rapid cooling were found. (6) Modal changes across this boundary are much sharper than those caused by gravitational fractionation in pillows. (7) The groundmass in the aphyric basalt is more coarse grained than in the phyric basalts, especially away from the chilled margins (Figure 15). This suggests that the aphyric basalts cooled relatively slowly. (8) Phenocryst size and habit are different in the phyric and aphyric basalts (Figure 15). For example, the average length of the plagioclase phenocrysts calculated from measurements of the long axes of the 30
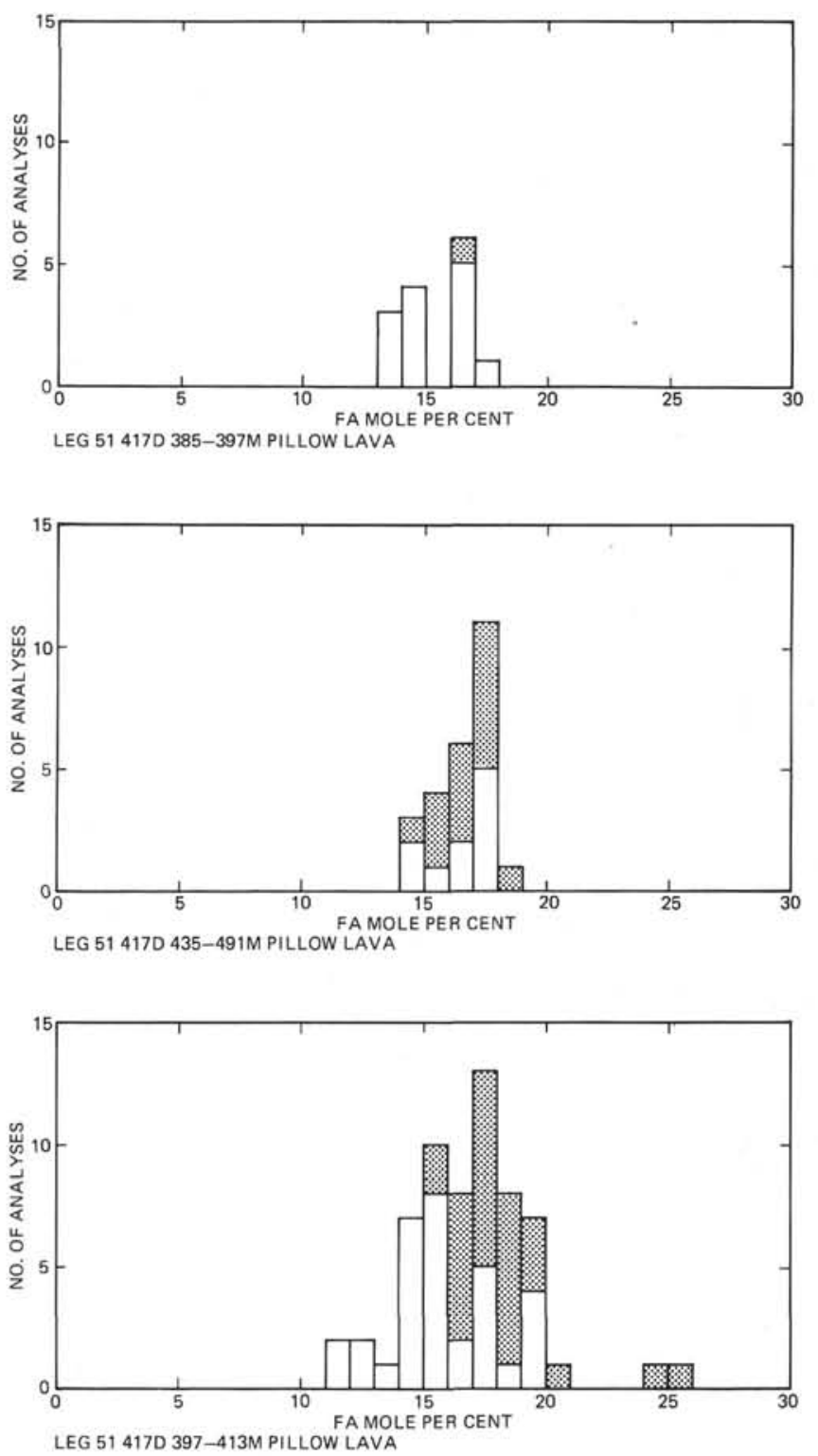

Figure 10. Histogram of the composition of olivine phenocrysts in Hole 417D. Open bars = phenocryst cores; and striped bars $=$ phenocryst rims and microphenocrysts.

TABLE 9

Averages of Partial Analyses of Groundmass Magnetite and Ilmenite From Hole 417D Basal ts

\begin{tabular}{c|ccc|cc}
\hline & \multicolumn{3}{|c|}{ Magnetite } & \multicolumn{2}{c}{ Ilmenite } \\
\cline { 2 - 7 } & $\begin{array}{c}365-397 \mathrm{~m} \\
\text { Pillow Lava }\end{array}$ & $\begin{array}{c}435-491 \mathrm{~m} \\
\text { Aphyric Basalt }\end{array}$ & $\begin{array}{c}501-532 \mathrm{~m} \\
\text { Pillow Lava }\end{array}$ & $\begin{array}{c}435-491 \mathrm{~m} \\
\text { Aphyric Basalt }\end{array}$ & $\begin{array}{c}501-532 \mathrm{~m} \\
\text { Pillow Lava }\end{array}$ \\
\hline No. of Analyses & 14 & 70 & 47 & 2 & 2 \\
$\mathrm{FeO}$ & $65.4 \pm 2.3$ & $65.9 \pm 2.3$ & $63.9 \pm 1.3$ & $49.8^{*} \pm 0.3$ & $48.2^{2} \pm 1.4$ \\
$\mathrm{TiO}_{2}$ & $20.4 \pm 1.4$ & $21.5 \pm 1.1$ & $22.3 \pm 0.9$ & $44.8 \pm 0.2$ & $42.2 \pm 0.7$ \\
$\mathrm{Al}_{2} \mathrm{O}_{3}$ & $2.49 \pm 0.46$ & $2.38 \pm 0.38$ & $2.24 \pm 0.33$ & $0.24 \pm 0.04$ & $0.76 \pm 0.0$ \\
\hline
\end{tabular}

largest phenocrysts within an area of $2.5 \mathrm{~cm}^{2}$ ranges from 0.8 to $1.0 \mathrm{~mm}$ in the aphyric basalts and from 1.0 to $1.4 \mathrm{~mm}$ in the phyric basalts. Prismatic plagioclase is common in the aphyric basalt, while tabular plagioclase is common in the phyric basalt (Figure 15). Modal plagioclase constitutes 4 to $9 \mathrm{vol} . \%$ of the aphyric basalt (Table 10) and 15 to $25 \mathrm{vol}$. \% 

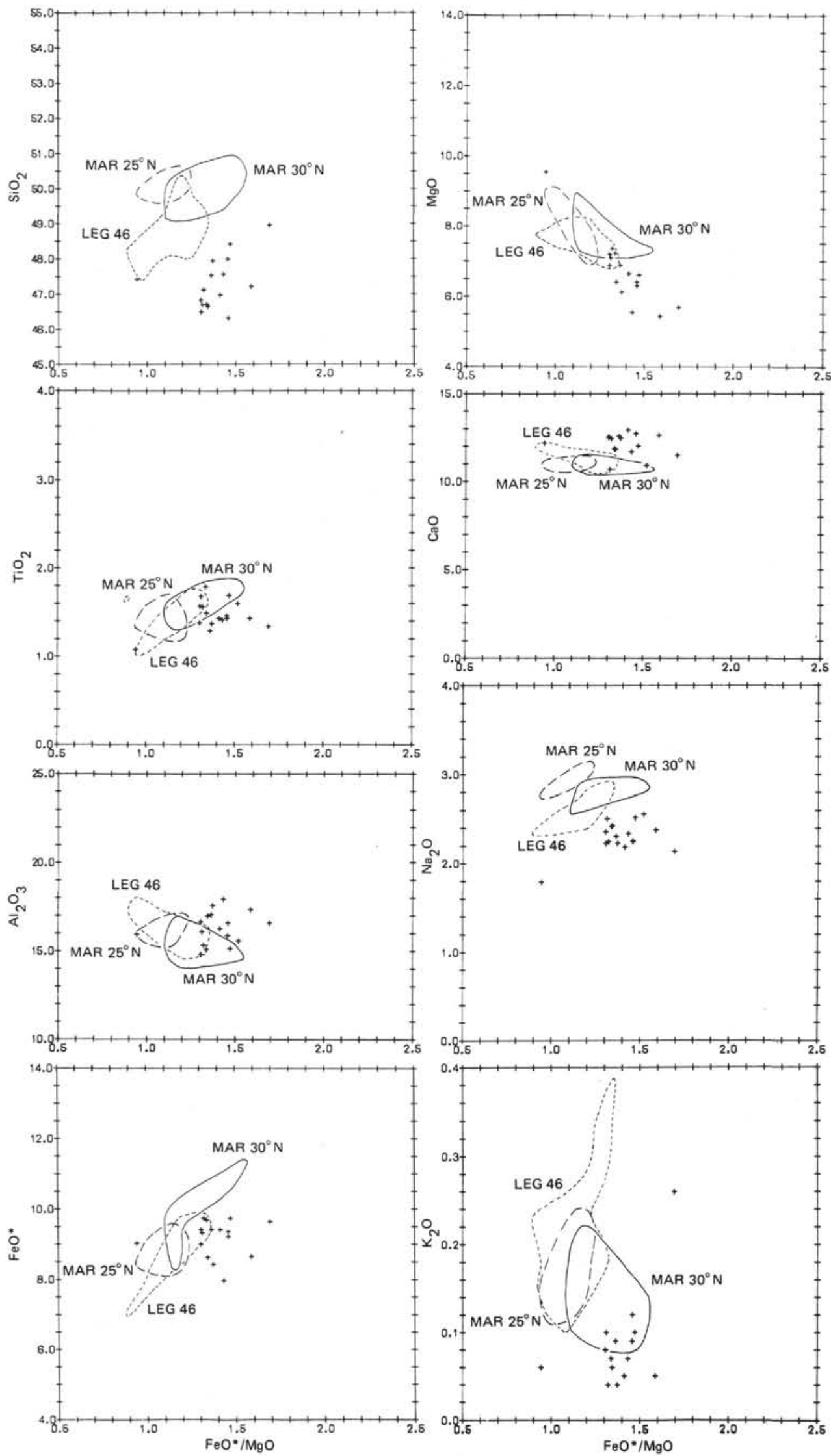

Figure 11. $\mathrm{FeO} * / \mathrm{MgO}$ variation diagram showing the bulk rock compositions of samples from Hole $417 \mathrm{D}$ (crosses), $25^{\circ} \mathrm{N}$, and $30^{\circ} \mathrm{N}$ on the Mid-Atlantic Ridge and Leg 46. 

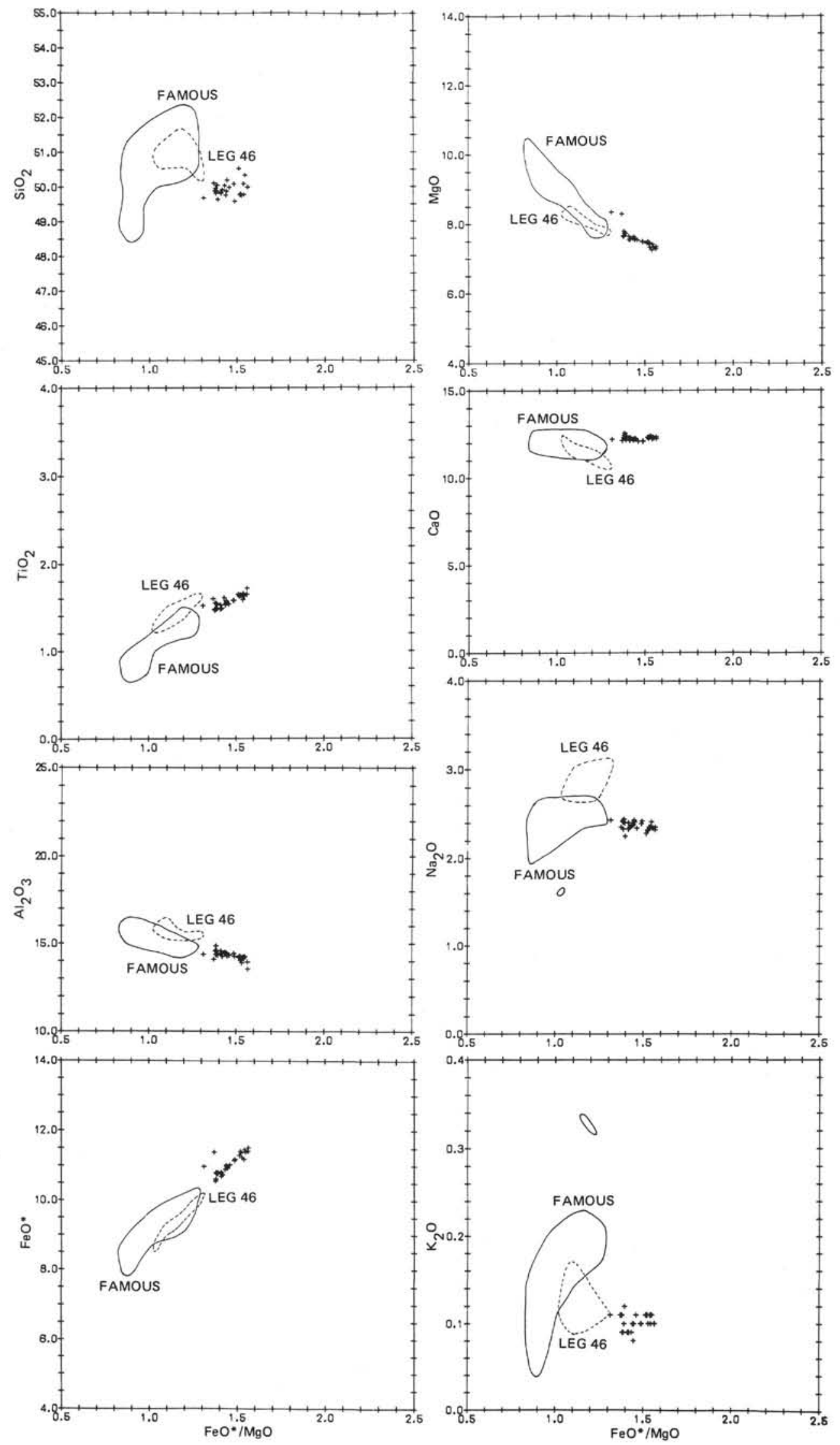

Figure 12. $\mathrm{FeO} / \mathrm{MgO}$ variation diagram showing the glass compositions of samples from Hole $417 D$ (crosses), the FAMOUS area, and Leg 46. 


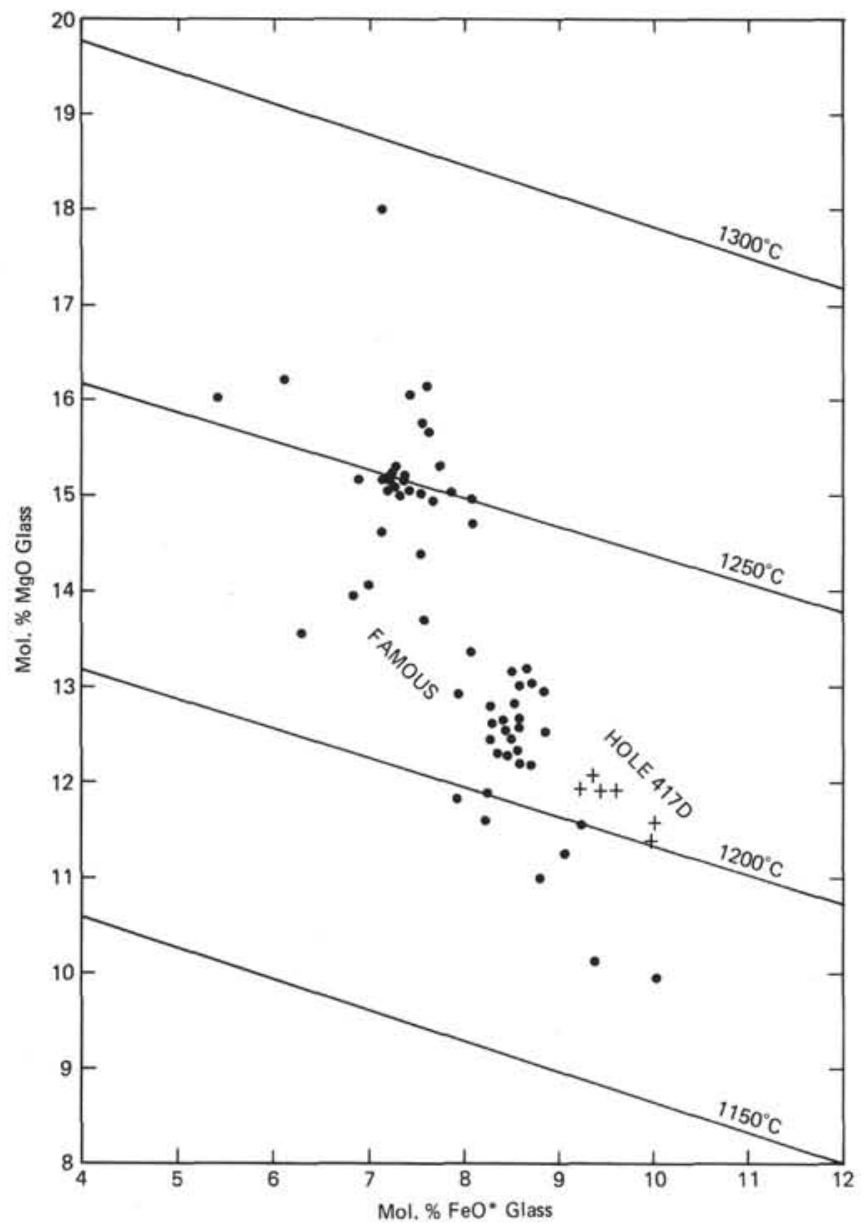

Figure 13. $\mathrm{Mol}$ \% $\mathrm{MgO}$ versus $\mathrm{FeO}^{*}$ in glass in equilibrium with olivine. Equilibrium temperature was determined using the geothermometer of Roeder and Emslie (1970). Crosses and circles represent data from Hole 417D and the FAMOUS area, respectively.

of the phyric basalt, with the percentage increasing toward the bottom of the hole (Figure 16). Mafic phenocrysts constitute 1 per cent to 2 per cent of the aphyric basalts and increase with depth in the phyric basalt to a maximum of 15 per cent by volume. The groundmass represents 86 per cent to 93 per cent of the aphyric basalt and decreases with depth in the phyric basalt (Figure 16). Only four bulk analyses are available for this flow - two from aphyric basalts, one from a basalt showing cumulate textures, and one from phyric basalt. Although the number of analyses is limited, a depletion of $\mathrm{Al}_{2} \mathrm{O}_{3}$ and $\mathrm{CaO}$ and a slight enrichment in $\mathrm{FeO}^{*}$ and $\mathrm{Na}_{2} \mathrm{O}$ are evident in the aphyric basalt. Eight analyses of chilled glass from five samples were also completed. Although data are lacking from the lower part of the flow, a slight increase in $\mathrm{Al}_{2} \mathrm{O}_{3}$ is evident toward the top of the unit. Compositional differences between plagioclase and clinopyroxene phenocrysts in the phyric and aphyric basalts are shown in Figures 7, 8, and 9. The plagioclase An content is lower in the phenocrysts, microphenocrysts, and groundmass of the aphyric basalt than in the phyric basalt, and the $\mathrm{FeO}^{*}$ content of the groundmass plagioclase is also lower in the aphyric basalt. At the same time, the clino-
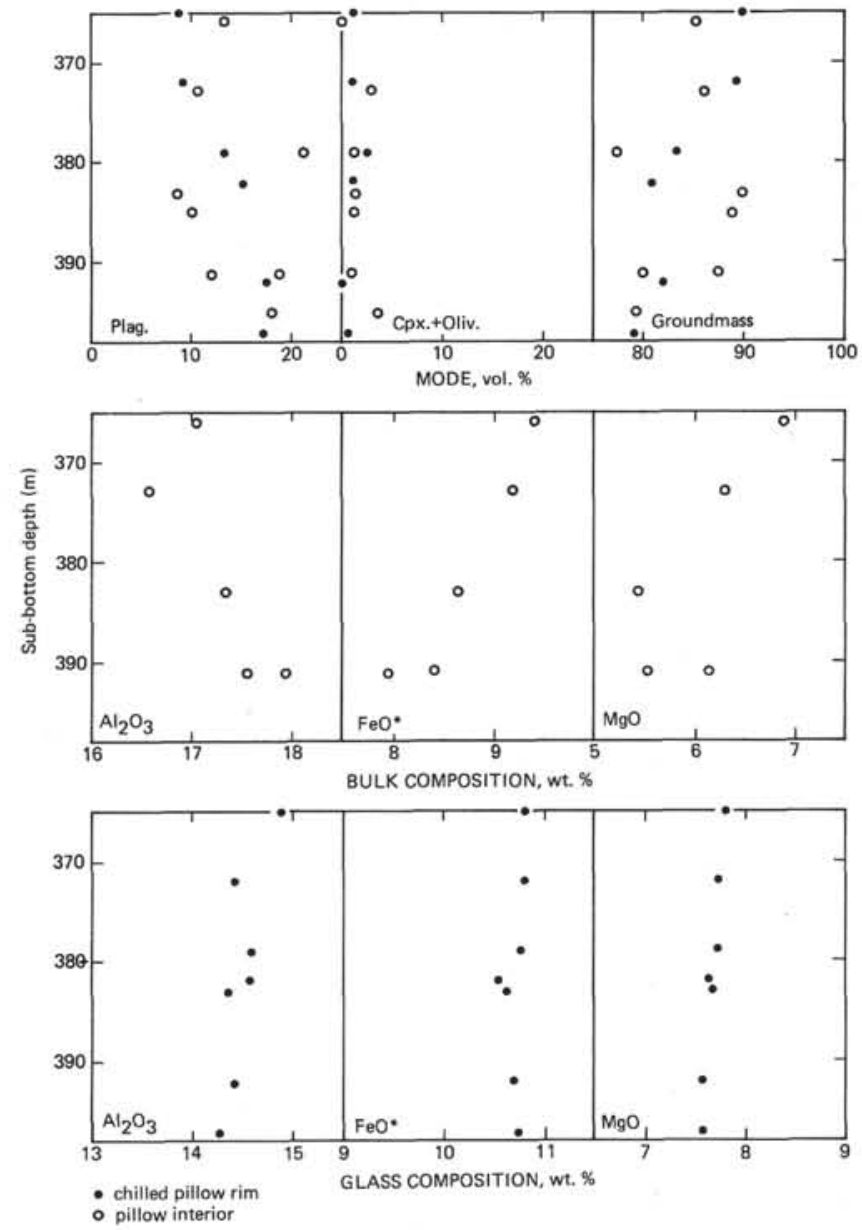

Figure 14. Depth versus modal analysis and composition for basalt and glass from 365 meters to 397 meters subbottom in Hole 417D.

pyroxene phenocrysts are richer in Fs in the aphyric basalts and the groundmass clinopyroxenes are poorer in $\mathrm{Ca}$. These data suggest that the aphyric basalt is slightly differentiated. This fairly sharp difference between the aphyric and the phyric basalts is difficult to explain by a model of intrapillow gravitational differentiation. Dike intrusion is one possible mechanism. If this is the case, the intrusion must have occurred soon after extrusion of the pillowed lava, for it does not show a chilled margin. Autointrusion of residual liquid from another part of the same pillow lava through minor lava tubes is also possible.

\section{SUMMARY}

We have proposed a revision of the unit boundaries defined on shipboard, using compositional and phase chemistry data. A major compositional gap is found at 491 meters sub-bottom in Hole 417D, and a compositionally zones pillow basalt flow is found between 365 and 397 meters subbottom. Aphyric zones within individual pillows are found in a pillow lava between 435 and 491 meters sub-bottom. These zones were formed by dike intrusion or autointrusion. The Site 417 basalts are slightly higher in $\mathrm{CaO}$ 
TABLE 10

Modal Compositions ${ }^{\mathrm{a}}$ of Hole 417D Basalt Samples

\begin{tabular}{|c|c|c|c|c|c|c|c|}
\hline \multirow{2}{*}{$\begin{array}{c}\text { Sample } \\
\text { (Interval in } \mathrm{cm} \text { ) }\end{array}$} & \multirow{2}{*}{$\begin{array}{l}\text { Depth in } \\
\text { Hole } \\
\text { (m) }\end{array}$} & \multicolumn{3}{|c|}{ Phenocryst } & \multirow[b]{2}{*}{ Groundmass } & \multirow[b]{2}{*}{ Vesicles } & \multirow[b]{2}{*}{ Veins } \\
\hline & & Plagioclase & Clinopyroxene & Olivine & & & \\
\hline $26-6,2-10$ & 365 & 8.6 & 0.1 & 0.7 & 89.7 & 0.5 & 0.4 \\
\hline $26-6,80-87$ & 366 & 13.3 & 0.0 & 0.1 & 85.2 & 1.2 & 0.0 \\
\hline $27-4,83-89$ & 372 & 8.9 & 0.0 & 1.0 & 89.6 & 0.5 & 0.0 \\
\hline $27-4,121-128$ & 373 & 10.5 & 0.2 & 2.6 & 86.3 & 0.2 & 0.2 \\
\hline $28-3,82-88$ & 379 & 13.1 & 0.0 & 2.4 & 83.4 & 0.3 & 0.8 \\
\hline $28-3,97-104$ & 379 & 21.3 & 0.0 & 1.2 & 77.5 & 0.0 & 0.0 \\
\hline $28-5,85-92$ & 382 & 15.3 & 0.1 & 1.0 & 80.9 & 0.0 & 2.7 \\
\hline $28-5,127-135$ & 383 & 8.7 & 0.0 & 1.3 & 90.0 & 0.0 & 0.0 \\
\hline $29-1,43-49$ & 385 & 9.9 & 0.0 & 1.1 & 89.0 & 0.0 & 0.0 \\
\hline $29-6,34-42$ & 391 & 18.7 & 0.0 & 1.1 & 80.1 & 0.1 & 0.0 \\
\hline $29-6,44-51$ & 391 & 12.1 & 0.5 & 0.6 & 87.5 & 0.3 & 0.0 \\
\hline $29-6,95-104$ & 392 & 17.4 & 0.0 & 0.1 & 82.3 & 0.2 & 0.0 \\
\hline $30-2,45-54$ & 395 & 18.0 & 0.0 & 3.5 & 79.4 & 0.1 & 0.0 \\
\hline $30-4,47-57$ & 397 & 17.3 & 0.0 & 0.4 & 79.2 & 0.6 & 2.5 \\
\hline $35-5,84-91$ & 444 & 21.1 & 0.4 & 2.4 & 74.8 & 0.0 & 1.3 \\
\hline $35-5,110-116$ & 444 & 20.4 & 0.2 & 1.8 & 77.0 & 0.6 & 0.0 \\
\hline $35-6,112-120$ & 445 & 19.5 & 0.0 & 0.2 & 79.9 & 0.3 & 0.1 \\
\hline $36-5,15-22$ & 451 & 21.4 & 1.1 & 0.4 & 76.0 & 0.3 & 0.8 \\
\hline $37-6,120-127$ & 458 & 14.7 & 0.5 & 3.8 & 80.6 & 0.2 & 0.2 \\
\hline $38-1,54-60$ & 459 & 22.2 & 0.3 & 0.8 & 75.3 & 0.1 & 1.3 \\
\hline $38-4,39-46$ & 461 & 21.7 & 3.5 & 1.7 & 72.9 & 0.0 & 0.2 \\
\hline $38-5,94-99$ & 463 & 13.8 & 1.7 & 1.2 & 82.4 & 0.1 & 0.8 \\
\hline $38-6,52-57$ & 464 & 3.8 & 0.0 & 2.2 & 92.8 & 1.2 & 0.0 \\
\hline $39-3,18-24$ & 467 & 9.5 & 0.0 & 2.0 & 86.5 & 0.2 & 1.8 \\
\hline $39-3,88-95$ & 468 & 8.6 & 0.0 & 0.9 & 89.9 & 0.0 & 0.6 \\
\hline $40-2,11-17$ & 473 & 16.7 & 0.5 & 4.3 & 78.3 & 0.2 & 0.0 \\
\hline $40-2,100-106$ & 474 & 28.6 & 0.2 & 4.7 & 66.1 & 0.0 & 0.4 \\
\hline $41-4,41-48$ & 479 & 22.4 & 0.3 & 0.7 & 74.6 & 0.1 & 1.9 \\
\hline $41-6,37-44$ & 482 & 28.1 & 1.0 & 1.5 & 69.4 & 0.0 & 0.0 \\
\hline $41-7,66-73$ & 483 & 25.6 & 2.0 & 6.2 & 65.9 & 0.3 & 0.0 \\
\hline $41-7,80-86$ & 484 & 22.9 & 0.5 & 7.5 & 69.1 & 0.0 & 0.0 \\
\hline $41-7,111-118$ & 484 & 26.8 & 11.0 & 3.4 & 58.6 & 0.2 & 0.0 \\
\hline $42-2,27-33$ & 487 & 24.5 & 2.2 & 2.4 & 70.4 & 0.5 & 0.0 \\
\hline
\end{tabular}

${ }^{\mathrm{a}}$ Vol. \%.

and $\mathrm{FeO} *$ than basalts found between $25^{\circ} \mathrm{N}$ and $37^{\circ} \mathrm{N}$ on the present Mid-Atlantic Ridge.

\section{ACKNOWLEDGMENTS}

We would like to thank E. Jarosewich for providing a sample of the interlaboratory standard WHOI No. AII 93-11-5 for comparison. The authors are indebted to Prof. S. Aramaki for his critical review of the manuscript and to Drs. H. Sato and T. Fujii for valuable discussions. Dr. H. Sato also provided technical assistance in operating the microprobe analyzer. Miss M. Okuda punched the data cards for computation. Mrs. H. Wada typed the manuscript.

\section{REFERENCES}

Bryan, W. B. and Moore, J. G., 1977. Compositional variations of young basalts in the Mid-Atlantic Ridge rift valley near lat. $36^{\circ} 49^{\prime}$ Geol. Soc. Am. Bull., v. 88, p. 556.

Bryan, W. B., Robinson, P. T., and Shipboard Party Leg 52, 1977. Studying oceanic layers, Geotimes, v. 22, no. 7/8, p. 22.

Donnelly, T. W., Francheteau, J., and Shipboard Party Leg 51, 1977. Mid-ocean ridge in the Cretaceous, Geotimes, v. 22, no. 6 , p. 21 .
Flower, M. F. J., Salisbury, M. H., and Shipboard Party Leg 53, 1977. Cretaceous crust sought, Geotimes, v. 22 , no. 9 , p. 20

Fujii, T. and Kushiro, I., 1978. Density and viscosity of basalt melt at high pressures (abstract), Internat. Geodynamics Conf., March 1978, Tokyo, p. 234.

Hart, R., 1970. Chemical exchange between sea water and deep ocean basalt, Earth Planet. Sci. Lett., v. 9, p. 269.

Hekinian, R., Moore, J. G., and Bryan, W. B., 1976. Volcanic rocks and processes of the Mid-Atlantic Ridge rift valley near $36^{\circ} 49^{\prime}$ N, Contrib. Mineral Petrol., v. 58, p. 83.

Miyashiro, A., Shido, F., and Ewing, M., 1969. Diversity and origin of abyssal tholeiite from the Mid-Atlantic Ridge near $24^{\circ}$ and $30^{\circ}$ north latitude, Contrib. Mineral. Petrol., v. 23, p. 38.

Poldervaart, A. and Hess, H. H., 1951. Pyroxenes in the crystallization of basaltic magma, J. Geol., v. 59, p. 472.

Roeder, P. L. and Emslie, R. F., 1970. Olivine-liquid equilibrium, Contrib. Mineral. Petrol., v. 29, p. 275.

Sato, H., Aoki, K., Okamoto, K., and Fujita, B., 1978. Petrology and chemistry of basaltic rocks from Hole 396B, IPOD/DSDP Leg 46. In Dmitriev, L., Heirtzler, J., et al., Initial Reports of the Deep Sea Drilling Project, v. 46: Washington (U.S. Government Printing Office), p. 115-142.

Shido, F., Miyashiro, A., and Ewing, M., 1974. Compositional variation in pillow lavas from the Mid-Atlantic Ridge, Marine Geol., v. 16, p. 177. 


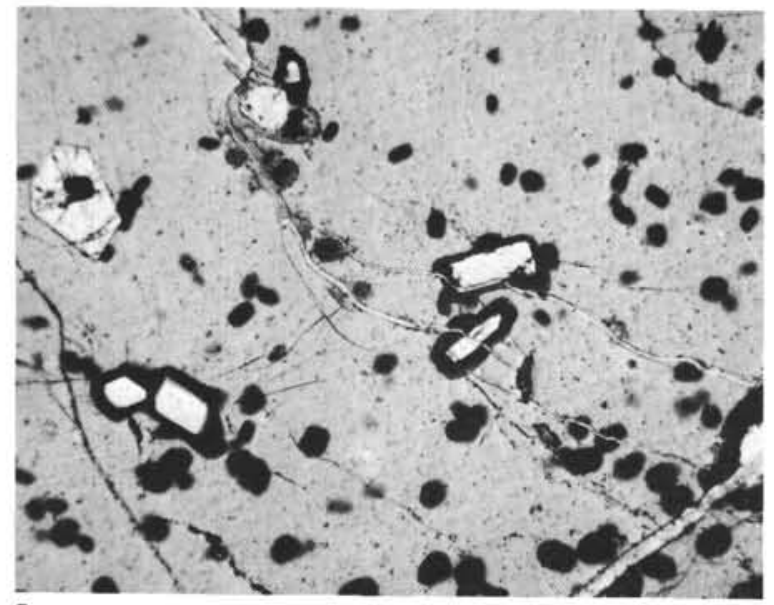

a
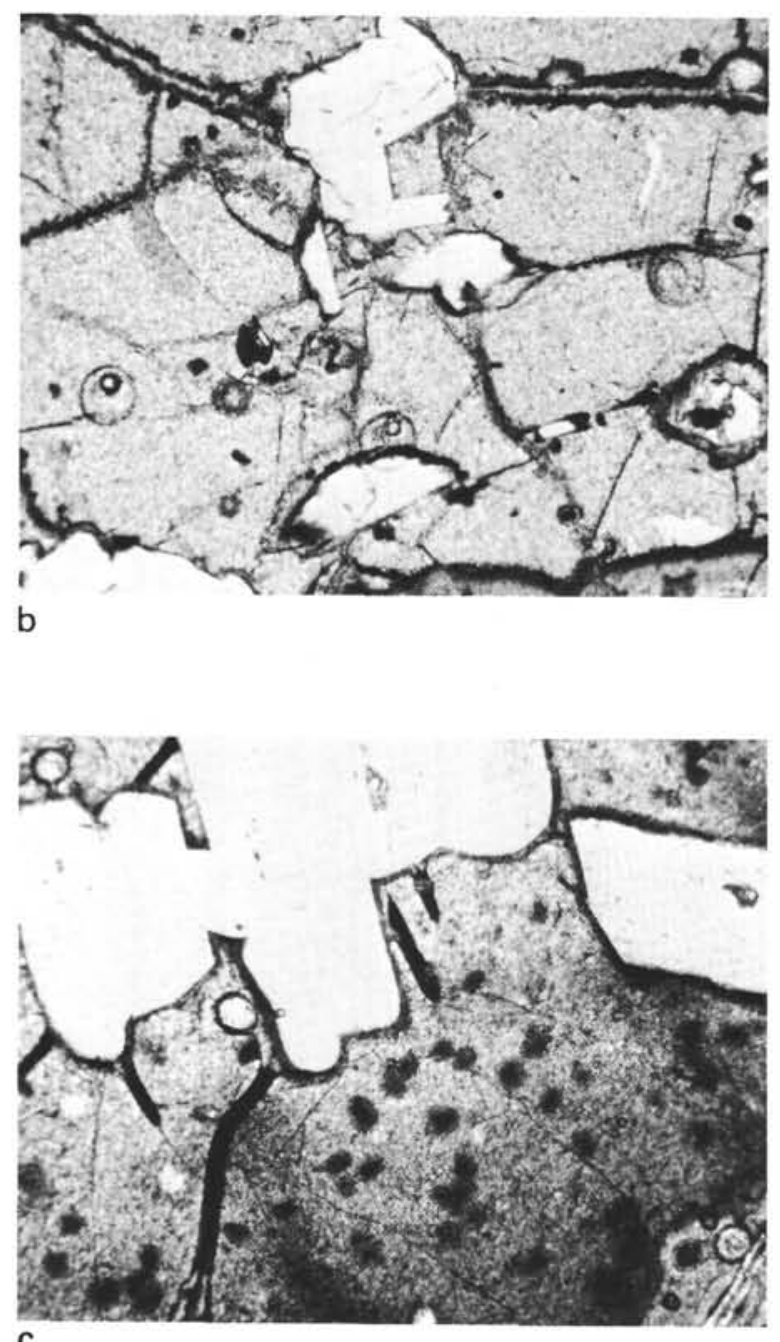
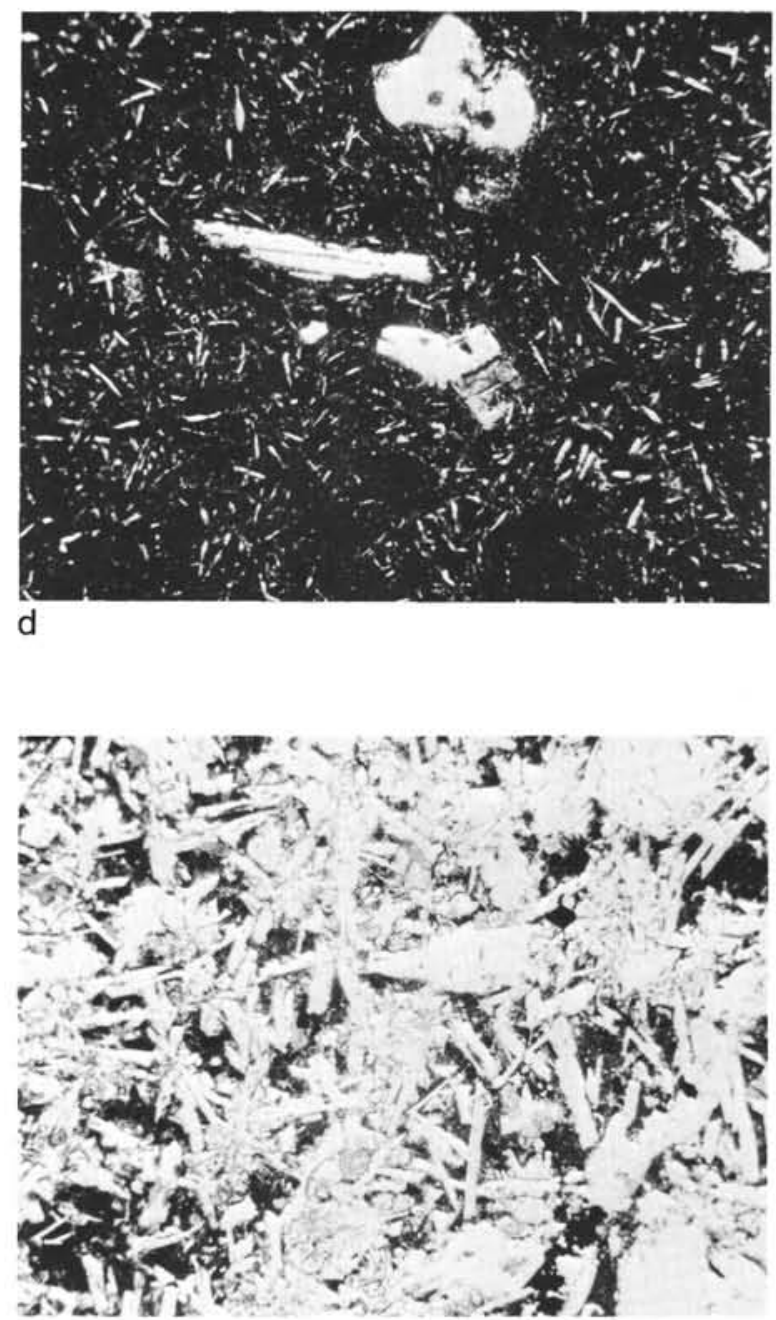

e

Figure 15. Photomicrographs showing modal and textural variations for 365 meter to 397 meter and 435 meter to 391 meter intervals in Hole 417D. Horizontal dimension is $2.5 \mathrm{~mm}$. (a) Sample 417D-26-2, 2-10 cm. Pillow margin showing plagioclase and fresh olivine phenocrysts in partially altered glass; (b) Sample 417D-27-4, 83-89 cm. Pillow margin showing plagioclase and partially altered olivine in glass; (c) Sample 417D-30-4, 47-57 cm. Plagioclase phenocrysts in basalts; note increasing amount and size of phenocrysts compared with $(a)$ and $(b)$; (d) Sample 417D-38-6, $52-57 \mathrm{~cm}$, vitrophyric texture in aphyric basalt; (e) Sample 417D-39-3, 18-24 cm, intersertal texture in aphyric basalt; and (f) Sample 417D-38-4, 39-46 cm, plagioclase and clinopyroxene phenocrysts and olivine pseudomorphs in variolitic basalt. 
T. UI, H. HARAMURA, H. NAGAI
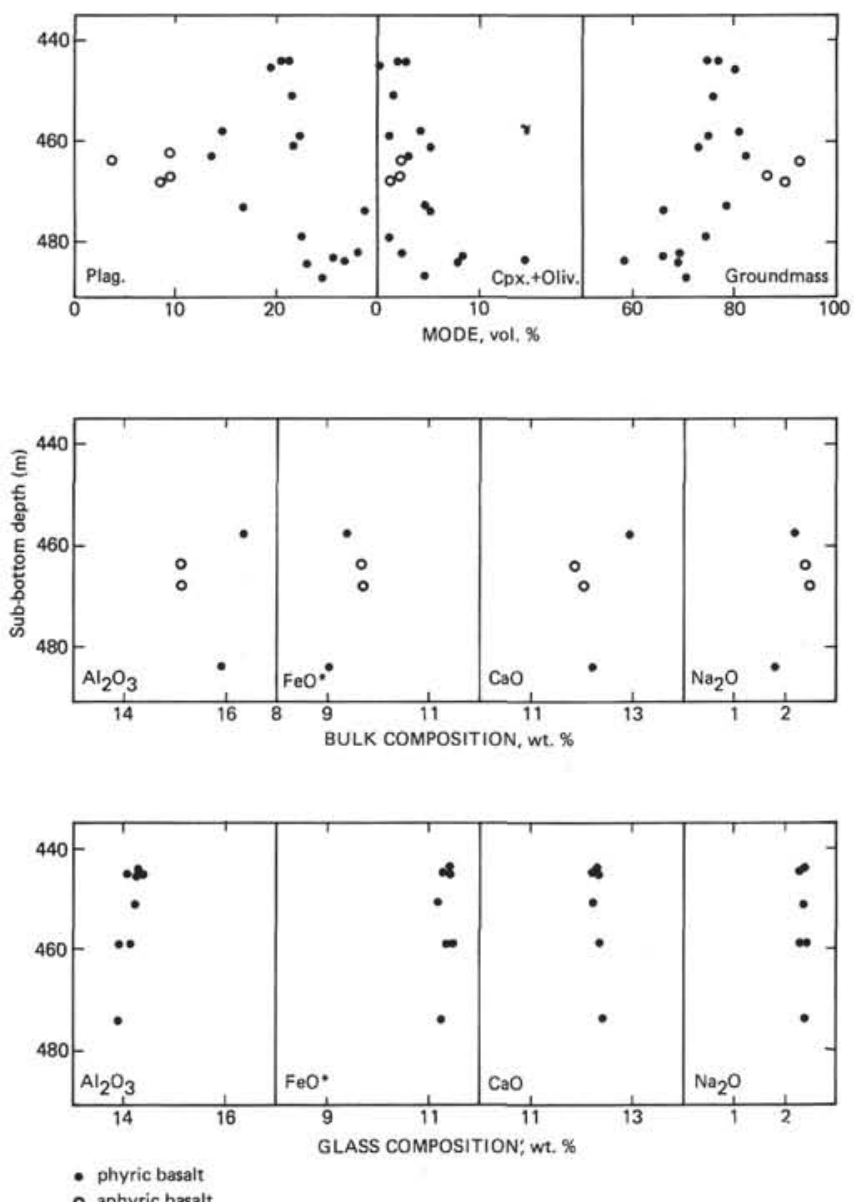

Figure 16. Depth versus modal analysis and composition for basalt and glass from the 435 meter to 491 meter interval in Hole 417D. 